\title{
An Operational Framework for Defining and Monitoring Forest Degradation
}

\author{
Ian D. Thompson ${ }^{1}$, Manuel R. Guariguata ${ }^{2}$, Kimiko Okabe $^{3}$, Carlos Bahamondez $^{4}$, Robert Nasi $^{2}$, Victoria Heymell $^{5}$ \\ and Cesar Sabogal
}

\begin{abstract}
Forest degradation is broadly defined as a reduction in the capacity of a forest to produce ecosystem services such as carbon storage and wood products as a result of anthropogenic and environmental changes. The main causes of degradation include unsustainable logging, agriculture, invasive species, fire, fuelwood gathering, and livestock grazing. Forest degradation is widespread and has become an important consideration in global policy processes that deal with biodiversity, climate change, and forest management. There is, however, no generally recognized way to identify a degraded forest because perceptions of forest degradation vary depending on the cause, the particular goods or services of interest, and the temporal and spatial scales considered. Here, we suggest that there are types of forest degradation that produce a continuum of decline in provision of ecosystem services, from those in primary forests through various forms of managed forests to deforestation. Forest degradation must be measured against a desired baseline condition, and the types of degradation can be represented using five criteria that relate to the drivers of degradation, loss of ecosystem services and sustainable management, including: productivity, biodiversity, unusual disturbances, protective functions, and carbon storage. These criteria are not meant to be equivalent and some might be considered more important than others, depending on the local forest management objectives. We propose a minimum subset of seven indicators for the five criteria that should be assessed to determine forest degradation under a sustainable ecosystem management regime. The indicators can be remotely sensed (although improving calibration requires ground work) and aggregated from stand to management unit or landscape levels and ultimately to sub-national and national scales.
\end{abstract}

Key Words: biodiversity; carbon; criteria and indicators; forest degradation; forest management; remote sensing

\section{INTRODUCTION}

Forest degradation is a widespread global concern and an important contemporary issue for several United Nations (UN) organizations and conventions. These groups include the UN Convention on Biological Diversity (CBD), which set a global target for restoration of at least $15 \%$ of degraded ecosystems by 2020 (Convention on Biological Diversity 2010); the UN Forum on Forests that has an objective to reduce degradation; the UN Convention to Combat Desertification (UNCCD) that considers degradation on drylands; and the UN Framework Convention on Climate Change (UNFCCC) that proposes to recover degraded forests as carbon sinks. Recent climate negotiations have initiated the concept of reducing emissions from deforestation and forest degradation (REDD) to mitigate climate change through forest management, including the restoration of degraded forests (UNFCCC 2010). Along with deforestation, forest degradation has major consequences for human societies and biodiversity, and significantly contributes to greenhouse gas emissions (Secretariat of the Convention on Biological Diversity 2002, Parry et al. 2007, van der Werf et al. 2009, Mery et al. 2010). Deforestation is an obvious ecosystem change, but forest degradation is more difficult to discern and quantify (Sasaki and Putz 2009). The International Tropical Timber Organization (ITTO 2002) suggests that up to 850 million ha of tropical forest could already be degraded.
The Millennium Ecosystem Assessment (e.g., Diaz et al. 2005) states that many forest provisioning and regulating services are being degraded, but does not discuss quantification or monitoring. The causes of degradation vary globally, including unsustainable logging, poor agricultural practices, invasive species, fuelwood gathering, and wildfire, with synergistic effects (van Wilgen et al. 2001, Asner et al. 2006, 2008, Chazdon 2008, Murdiyarso et al. 2008, Kissinger et al. 2012).

Although there are numerous definitions of forest degradation (Simula 2009), many are reductionist (e.g., Parry et al. 2007), and none is adequate to inform decision making. There is a growing need to be able to identify a degraded forest from stand scales to landscape and national scales to inform decision making about where to invest in forest recovery (e.g., Holl and Aide 2011). The lack of an agreed common definition (and monitoring framework) hinders international recovery efforts (Sasaki and Putz 2009). The recently completed Global Forest Resources Assessment (FAO 2010) could not report an area of degraded forest for lack of a definition. In general, definitions of forest degradation (ITTO 2002, Secretariat of the Convention on Biological Diversity 2002, Norris 2012) suggest changes in forest structure, dynamics, and functions resulting mostly from human-induced causes relative to a preferred condition. In these latter definitions, the spatial scale 
is at the stand or site level, and the temporal scale is usually long term. The Collaborative Partnership on Forests (CPF, www.cpfweb.org) tries to reconcile the many definitions and proposes that forest degradation is the "reduction of the capacity of a forest to provide goods and services". Although this definition is also not operational, it provides a basis for assessing degradation through quantifiable indicators of ecosystem goods and services.

Perceptions about forest degradation are varied and depend on the causes, the goods or services of interest, and the temporal scale considered. Forest degradation has been described using variables such as changes in canopy and understory tree density, plant or animal species richness, and/ or carbon stocks as measured against a baseline from apparently undisturbed conditions (Lambin 1999, Devi and Behera 2003, Harrison 2011). Some authors consider tropical forests to be degraded once the forest has been logged (e.g., Sierra 2001, Foley et al. 2007), whereas others consider this only when the forest has been heavily burned and logged (Souza et al. 2005). Furthermore, societal choices largely determine what is considered degraded. For example, a manager who replaces a primary forest with a tree plantation to supply a sustained yield of wood is unlikely to perceive that forest as degraded. The same plantation, however, is less capable of providing other goods and services supplied in primary forests because of reduced biodiversity (e.g., Brockerhoff et al. 2008, Thompson et al. 2009). Slash-andburn agricultural landscapes are degraded compared to wellmanaged forests, but not in the context of livelihood options (Schmidt-Vogt 1998). Similarly, unsustainable logging may degrade timber stocks and soils but enhance the yields of nontimber forest products (NTFPs) important to local communities (e.g., Salick et al. 1995). In terms of landscape sustainability, however, forest degradation should be considered with respect to multiple ecosystem goods and services that could be derived under sustainable ecosystem management. Consistent with the CPF definition, we suggest that forest degradation represents changes to ecosystem processes and a continuum of decline in services from levels in primary forests (i.e., unaltered by humans except for traditional forest uses), through various forms of human use and (mis-)management, to deforestation (see e.g., Chazdon 2008).

Here, we propose a suite of criteria and indicators that can be used by forest managers, and interpreted by policy makers, to quantify types of forest degradation according to specific circumstances and objectives. The indicators enable tests of hypotheses relative to expected conditions of ecological integrity. We have organized this paper as a series of sections that provide a discussion of the selected criteria and indicators, followed by a discussion of our approach to a minimum subset of indicators that could be immediately applied sub-nationally, nationally, and globally.

\section{CRITERIA AND INDICATORS FOR DEFINING FOREST DEGRADATION}

We selected our criteria based on the following considerations: relationship to the main causes of forest degradation (e.g., Kissinger et al. 2012); relationship to the provision of ecosystem services as defined in the Millennium Ecosystem Assessment (Diaz et al. 2005); relevance to variables reported in the Global Forest Resources Assessment (e.g., FAO 2010); potential for the application of remote sensing for monitoring; and relevance to reporting requirements for sustainable forest management (SFM), as required, for example, by the Montréal Process (2009), the Ministerial Conference on the Protection of Forests in Europe (Vienna, Liaison Unit 2003), and the Lapaterique Process (FAO 2002). SFM and forest degradation are related, but opposite, concepts, and so several SFM criteria can also be degradation criteria. Based on these considerations, we selected five criteria to determine degradation: productivity, biological diversity, unusual disturbances, carbon storage, and protective functions. We included carbon stock as a separate criterion, despite its close link to productivity, because of its high relevance to UNFCCC in the context of emissions reductions and for forest-carbon projects. These five criteria should not be viewed as necessarily equivalent; we expect that certain criteria might be considered more important than others, depending on local or national circumstances and on the objectives for a particular forest. However, under an ecosystem management regime, all criteria should be considered. For each criterion, we suggest using some existing SFM indicators (e.g., Siry et al. 2005), and we propose several others. Monitoring the indicators for each criterion enables the CPF definition of forest degradation to become operational. Although we do not provide guidance for monitoring, most of the suggested indicators have been assessed using remote sensing (Tables 1 and 2). We provide a review of the use of remote sensing to measure forest degradation.

\section{Indicators and spatial scale}

Degradation is ecosystem- and location-dependent in terms of parameters that might be measured, e.g., a particular species or certain forest goods. Stand-level assessments are required for local understanding, but the indicators must also be applicable for forest management units and at sub-national and national levels for international reporting purposes (e.g., to CBD; e.g., Sasaki and Putz 2009). Hence, the indicators must be unambiguous, readily repeatable, and provide quantitative data to assess trends over time (e.g., Gardner 2010) and also allow for scaling up. Management decisions about forest removals are often taken for large areas and not only for individual stands. Therefore, forest degradation will be most effectively reported for landscapes; these are usually locally defined areas > 5000 ha. Such landscapes will necessarily contain multiple stand types and conditions that often reflect forest recovery under natural or assisted processes, which may or may not be degraded. 
Table 1. A suggested framework of criteria and indicators for defining and delineating areas of degraded forest. A suggested minimum set of seven indicators is indicated by an asterisk $(*)$.

\begin{tabular}{|c|c|c|c|}
\hline Criterion & Indicator(s) & Variable(s) & General methods \\
\hline \multirow[t]{2}{*}{ Production } & Growing stock* & $\mathrm{m}^{3} / \mathrm{ha}$ of wood & Satellite imagery, LiDAR, ground plots \\
\hline & Nontimber forest products & Monetary value, number/yr & $\begin{array}{l}\text { Country reporting, questionnaires by } \\
\text { management unit }\end{array}$ \\
\hline \multirow[t]{3}{*}{ Biodiversity } & Ecosystem state* & Area of specific forest type & Satellite imagery \\
\hline & Fragmentation* & Area fragmented & Satellite imagery, aerial photography \\
\hline & Species & $\begin{array}{l}\text { Presence/absence, population density, } \\
\text { relative abundance, indicator of } \\
\text { abundance }\end{array}$ & Aerial or ground surveys \\
\hline \multirow[t]{2}{*}{ Unusual disturbances } & Invasive species* & Population density, area affected & $\begin{array}{l}\text { Satellite imagery, aerial photography, } \\
\text { ground surveys }\end{array}$ \\
\hline & Fire* & Area affected & Satellite imagery, aerial photography \\
\hline \multirow[t]{2}{*}{ Protective function } & Soil erosion* & Area affected & Satellite imagery, aerial photography \\
\hline & Water volume or flow & Flow rate & River or stream flow meters \\
\hline \multirow[t]{2}{*}{ Carbon storage } & Stored carbon* & Biomass/ha & Satellite imagery, ground plots \\
\hline & $\begin{array}{l}\text { High wood-density trees } \\
\text { species }\end{array}$ & Tree density, relative abundance & Ground plots, aerial photography \\
\hline
\end{tabular}

\section{Reference condition}

Degradation is both a state (i.e., the forest is degraded) and a process as a continuum across time and/or space (i.e., the forest is being degraded; Chazdon 2008, Ahrends et al. 2010). With one exception (i.e., forest ecosystem state) our indicators address levels or amounts of degradation as a process. In all cases, reference conditions specific to a forest ecosystem type are needed against which to determine the occurrence and extent of degradation (e.g., Huettner et al. 2009). Forests change continuously through natural processes (e.g., climatic variation); although forests are normally resilient and resistant to such processes (e.g., Thompson et al. 2009), understanding the range of natural variability in the parameters of interest through space and time (Keane et al. 2009) is a prerequisite to measuring forest degradation (Fig. 1). When an indicator of forest condition is measured as being consistently below a specified level (i.e., from several measurements over time), the forest should be considered degraded. Therefore, repeated measurements are essential.

An appropriate reference state must be selected with care. Primary forests can provide a baseline against which to measure degradation, including in various successional stages. Natural forest, however, should not be the sole reference state considered because this implies that SFM degrades a forest, resulting in confusion about what is and is not degraded. Clearly, unplanned and poor logging practices are often the precursors to other human interventions leading to further degradation and ultimately to deforestation over time (Nepstad et al. 1999, Asner et al. 2006). Nevertheless, although a sustainably logged tropical forest stand may not necessarily contain a complete biodiversity complement (e.g., Asner et al. 2006, Lewis 2009, Klimes et al. 2012), SFM has dramatically
Fig. 1. Degradation must be measured against a desired baseline, and the natural variation of that baseline must be understood. The upper nonmonotonic line represents natural variation of an indicator over time (e.g., annual fluctuation) and enables the calculation of baseline variance. If the trajectory consistently falls into the red zone, as does the orange line, the forest should be considered degraded with respect to the particular indicator and criterion.

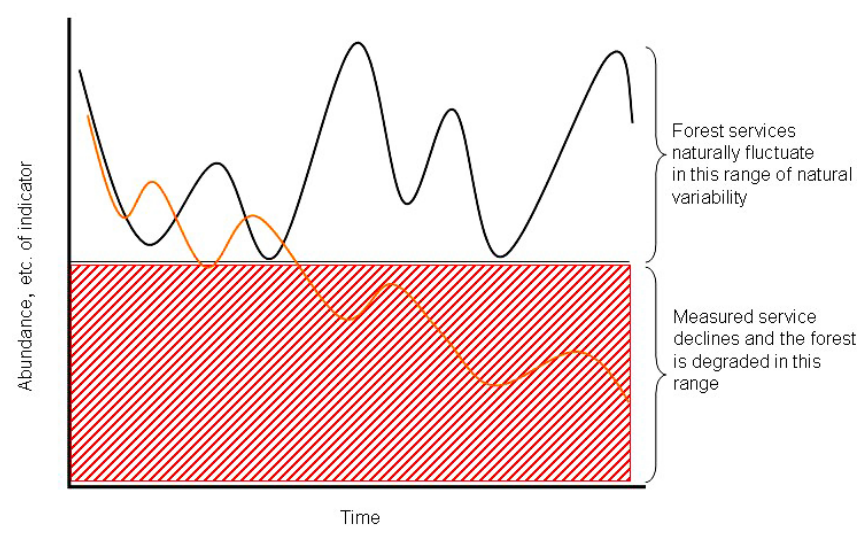

improved forest conservation (e.g., Foley et al. 2007, PeñaClaros et al. 2007, Putz et al. 2007, 2012, Edwards et al. 2011). Allowable removals can be determined for goods or services based on expected pre-defined management objectives; if these are properly established, they can serve as baseline values. Therefore, the appropriate baselines for indicators should be a combination of what would normally be expected 
Table 2. Examples of studies that have used remote sensing to report on the minimum set of suggested indicators of forest degradation (from Table 1).

\begin{tabular}{|c|c|c|c|c|}
\hline Indicator & Study & Location & Methods & Results/outputs \\
\hline \multirow[t]{3}{*}{ Growing stock } & Hollaus et al. 2009 & Austria & LiDAR and ground & LiDAR canopy correlated to growing stock \\
\hline & Gallaun et al. 2010 & Europe & Satellite and ground & $\begin{array}{l}\text { MODIS model for aboveground biomass } \\
\text { for Europe }\end{array}$ \\
\hline & Souza et al. 2005 & Brazil & Satellite and ground & $\begin{array}{l}\text { Landsat TM model comparing biomass of } \\
\text { primary and degraded forests }\end{array}$ \\
\hline \multirow[t]{2}{*}{ Ecosystem state } & Strand et al. 2007 & Summary report & Satellite & $\begin{array}{l}\text { Multiple examples of Landsat, ASTER, } \\
\text { SPOT HRV mapping of forest types at } 15 \\
\text { to } 250-\mathrm{m} \text { resolution }\end{array}$ \\
\hline & Souza et al. 2005 & Brazil & Satellite & $\begin{array}{l}\text { Classification and mapping of forest types } \\
\text { using Landsat TM and ETM }\end{array}$ \\
\hline \multirow[t]{3}{*}{ Fragmentation } & Harper et al. 2007 & Madagascar & Satellite & $\begin{array}{l}\text { Landsat used to estimate decline in forest } \\
\text { cover over time }\end{array}$ \\
\hline & Achard et al. 2002 & Global & Satellite & $\begin{array}{l}\text { Rate of fragmentation and loss of tropical } \\
\text { humid forests for } 1990-1997\end{array}$ \\
\hline & $\begin{array}{l}\text { Sánchez-Azofeifa et al. } \\
2001\end{array}$ & Costa Rica & Satellite & $\begin{array}{l}\text { Fragmentation index derived showing } \\
\text { change over time with Landsat TM }\end{array}$ \\
\hline \multirow[t]{6}{*}{ Alien invasive species } & Theron et al. 2004 & South Africa & Satellite and ground & $\begin{array}{l}\text { Mapping invasion by Acacia using Landsat } \\
\text { ETM }\end{array}$ \\
\hline & Ferreira et al. 2005 & Portugal & Aerial photography & Mapping invasion by Pinus pinaster \\
\hline & Tsai et al. 2007 & Taiwan & Satellite & $\begin{array}{l}\text { Mapping invasion by Leucaena } \\
\text { leucocephala using hyperspectral imagery }\end{array}$ \\
\hline & Le Maître et al. 2002 & South Africa & Aerial photography & Mapping invasion by Acacia \\
\hline & Everitt and Deloach 1990 & USA, Mexico & Aerial photography & Mapping invasion by Tamarix chinensis \\
\hline & Pontius et al. 2008 & USA & Satellite & $\begin{array}{l}\text { Mapping area damaged by Agrilus } \\
\text { planipennis using hyperspectral images }\end{array}$ \\
\hline \multirow[t]{3}{*}{ Fire } & Souza et al. 2005 & Brazil & Satellite & Area mapping using Landsat TM and ETM \\
\hline & Dennis and Colfer 2006 & Indonesia & Satellite & Area mapping using Landsat TM and ETM \\
\hline & Matricardi et al. 2010 & Brazil & Satellite & Area mapping using Landsat \\
\hline \multirow[t]{4}{*}{ Soil erosion } & Prasannakumar et al. 2011 & India & Satellite and ground & Quantifying erosion area \\
\hline & Maya et al. 2004 & Mexico & Satellite & Quantifying erosion area using SPOT \\
\hline & Lu et al. 2004 & Brazil & Satellite & $\begin{array}{l}\text { Mapping of erosion and erosion potential } \\
\text { using Landsat ETM }\end{array}$ \\
\hline & Manchanda et al. 2002 & India & Satellite & Mapping of erosion and erosion potential \\
\hline \multirow[t]{5}{*}{ Stored carbon } & Baccini et al. 2012 & Global tropical & Satellite & $\begin{array}{l}\text { Carbon density mapping using satellite } \\
\text { LiDAR }\end{array}$ \\
\hline & Ryan et al. 2012 & Mozambique & Satellite & $\begin{array}{l}\text { Aboveground biomass mapping using } \\
\text { synthetic aperture radar ( } 0.06 \text { ha } \\
\text { resolution) }\end{array}$ \\
\hline & Saatchi et al. 2011 & Global tropical & Satellite & $\begin{array}{l}\text { Carbon density mapping using satellite } \\
\text { LiDAR }\end{array}$ \\
\hline & Goetz et al. 2009 & Africa & $\begin{array}{l}\text { Satellite, LiDAR, } \\
\text { ground }\end{array}$ & Comparison among methods \\
\hline & DeFries et al. 2006 & Global tropical & Satellite & $\begin{array}{l}\text { Carbon density mapping using MODIS } \\
\text { and Landsat }\end{array}$ \\
\hline
\end{tabular}

for that particular forest type, either as a primary forest or a sustainably managed forest with specified values for emphasized goods and services.

\section{CRITERION 1: PRODUCTIVE FUNCTIONS}

The long-term production of forest goods and services is a key objective of SFM, and the harvesting of forest goods is not considered degradation unless it leads to significant reductions in availability (Chazdon 2008). Forest degradation may result in lower future biomass accumulation in recovering forests owing to a shift in species composition (i.e., ecosystem state; see Criterion 2) and tree size class structure, loss of highly functional species (Díaz and Cabido 2001, Russell et al. 2010), and/or a reduction at the landscape scale of mature forests (for example, Kirby and Potvin 2007, Lewis et al. 2009).

Production can be assessed by comparing the harvesting of forest goods to sustainable levels defined in a forest management plan. Examples of common indicators of timber production include the annual allowable cut, mean annual increment (MAI), and stocking density (e.g., Seidl et al. 2007). In cases of subsistence use of forest goods, evidence of resource degradation can be assessed by monitoring sequential reductions in the abundance, density, and/or size class distribution in a forest over time or over a given distance from 
a defined point (e.g., Ahrends et al. 2010). Degradation of productive functions may be best estimated by assessing changes in growing stock and measures of the production of specific NTFPs. Carbon is a separate criterion (see Criterion 5 ), but clearly part of total forest biomass is estimated from growing stock.

\section{Indicators of production}

Growing stock

Growing stock is the standing volume of all trees (or selected commercial species) of a specified diameter and height in a forest area and can be measured as stocking density $\left(\mathrm{m}^{3} / \mathrm{ha}\right)$, basal area $\left(\mathrm{m}^{2} / \mathrm{ha}\right)$, or total volume $\left(\mathrm{m}^{3}\right.$; e.g., FAO 2005$)$. Growing stock is often estimated through field measurements using large-scale forest inventories (Bahamóndez et al. 2009). Minimum values for stocking density by forest type (and commercial tree species) and geographic zone must be established as reference values to determine if the actual growing stock can be considered adequate (undegraded; e.g., Phat et al. 2004); these equations already exist widely. Estimates of growing stock can be used to evaluate and monitor the potential of a forest for timber and fuelwood production. An annual allowable cut is the most common growing stock estimate, for a given time period, and can be used to monitor forest production and set limits for sustainable use (e.g., Seidl et al. 2007). Growing stock is usually reported as an aggregate figure for all commercial species, but can be reported by species, species groups, or stands. Information on growing stock is essential for understanding the ecological dynamics and productive capacity of forest stands, enabling managers to stay within the limits of sustainability. Degraded production refers to reduced growing stock, population declines of certain tree species, and diminished reproductive capacity of commercial species or targeted population levels (e.g., abandoned or exhausted coppices in certain forest types) relative to baseline values (Chazdon 2008). Although more difficult to assess in cases of subsistence management, growing stock degradation can be recognized through sequential reductions in abundance, density, and/or size class distribution in a forest, either over time or distance from a defined point (e.g., Ahrends et al. 2010). Loss or reduced populations of selectively harvested tree species are discussed under Criterion 2: Biodiversity, but also apply well as an indicator of productivity (e.g., Kirby and Potvin 2007).

For fuelwood and charcoal, national-level forest statistics on production and consumption tend to be gross estimates based on demographic data and estimated consumption per household (e.g., Girard 2002). Direct measurements of the resource and supply are more accurate and should be encouraged, particularly for dry tropical forests, where fuelwood and charcoal may be the principal uses of wood (Girard 2002). At a sub-national level, the supply of fuelwood can be determined by quantifying growing stock of species used for charcoal and their expected and realized annual increments.

Various remote sensing techniques for assessing growing stock have been developed using aerial photography, satellite imagery, and more recently using LiDAR imaging from aircraft, based on correlations to ground data (Table 2). Several studies suggest that primary or well-managed forests vs. degraded forests can be detected readily via satellite remote sensing (e.g., Souza et al. 2005, Harper et al. 2007, Olander et al. 2008, Asner et al. 2009, Matricardi et al. 2010, Matsushita et al. 2010).

\section{Nontimber forest products (NTFPs)}

NTFPs contribute to local economies and include traditional medicines (e.g., Shanley and Luz 2003, Shackleton et al. 2007). The diversity of species, distribution patterns, or seasonality of plants providing NTFPs require specific sampling designs for quantification. Therefore, assessments of NTFPs have had to focus on areas where commercial collection is concentrated or that are known as excessively used for subsistence consumption. Countries report estimates of consumption of commercially important NTFPs (e.g., FAO 2010); however, the reliability of these estimates is questionable because the consumption is often local and is not recorded (Vantomme 2003, Shackleton et al. 2007), and some products originate from areas not classified as forest (FAO 2010). National-level data do not account for variation by geographical zones or among forest types.

We suggest that social and socioeconomic indicators can be used as proxies for NTFPs, with the caveat that these indicators must be adjusted for other factors that may influence NTFPs. Social indicators can help to validate information obtained through direct measurement. For example, Kleine et al. (2009) noted that local knowledge about the absence of desired forest products and services assisted in describing the level of forest degradation in India. Similarly, medicinal plant depletion was reported in an area of Brazil (Shanley and Luz 2003). Data on household consumption can be collected using rapid rural assessments such as those specified in the Poverty-Forest Linkages toolkit (PROFOR 2010). The methods of Ahrends et al. (2010) for assessing growing stock (see above) could be applied to production of NTFPs. More directly, age and size distributions of plant species used for NTFPs, at the stand or landscape levels, could be measured. For example, Peres et al. (2003a) determined the sustainability of Brazil nut harvesting across Bolivia, Brazil, and Peru by assessing use relative to tree population. Such data could be compiled over time and, assuming constant demand, reduced use of NTFPs may indicate a reduction in supply.

\section{CRITERION 2: BIODIVERSITY}

Biodiversity provides essential ecosystem functions in forests such as pollination, decomposition, seed dispersal, carbon 
sequestration, pest and disease reduction, and emergent properties such as resilience (e.g., Balvanera et al. 2006). Reduced biodiversity often directly affects forest processes that produce goods or services (e.g., Díaz et al. 2003, Thompson et al. 2009), although species redundancy may retard visible effects on processes (Walker 1992). Nevertheless, reduced biodiversity is directly related to lower levels of many goods and services, particularly if the losses involve highly functional species (e.g., Díaz and Cabido 2001, Balvanera et al. 2006), key tree species used for wood products (Kirby and Potvin 2007), or food animals (Harrison 2011). For example, empty forests syndrome (e.g., Redford 1992, Harrison 2011) is a cryptic form of degradation in which animal species have been overexploited for food but there is no obvious change in forest structure or in the supply of other goods. Loss of animal species may eventually result in ecosystem degradation because of the loss of seed dispersal and changes in herbivory (e.g., Wright et al. 2007, Terborgh et al. 2008). Forest landscapes can become degraded from a biodiversity perspective through the loss of species, genes, forest types, forest fragmentation, or the large-scale conversion of forest ecosystems to other forest types. While biodiversity effects on ecosystem functioning occur at all scales (e.g., Balvanera et al. 2006), we suggest that species and landscape indicators are most appropriate to monitor degradation. We propose three indicators for biodiversity: ecosystem state, fragmentation, and selected species.

\section{Indicators of biodiversity}

\section{Ecosystem state}

Forest ecosystem state, or type, is the recognizable normal species composition and structure of the dominant trees for a given site, and a change in state refers to a change in species composition of the vegetative cover. Forests are normally resilient to natural disturbances within bounds and recover following major disturbances (Gunderson 2000, Folke et al. 2004, Walker et al. 2004), but a loss of biodiversity from excessive disturbances will often reduce that capacity, resulting in different vegetation (Folke et al. 2004, Thompson et al. 2009). Such changes in forest state may result in changes in processes, degrading the production of goods and services (Diaz et al. 2005, Pardini et al. 2010). Recovery of the original forest state is unlikely without management (e.g., Gunderson 2000, Macdonald 2004).

Classifications of forest ecosystems (dynamic complexes of plant, animal, and micro-organism communities and their nonliving environments) can be made at various scales (Allen and Hoekstra 1992), so the ecosystem state indicator can refer to individual stands or forest landscapes. At the landscape scale, classifications are broad forest types such as tropical dry forest or tropical rainforest (e.g., FAO 2001), and a change in state represents a major change in vegetation such as, for example, from dry forest to savannah. At finer scales, classification of forest types is based on plant associations, elevation, moisture, and soil types (e.g., Swaine and Hall 1976, Letouzey 1985, Slik et al. 2009).

At the stand level, change in state refers to a different stand type such as an open canopy forest instead of closed canopy forest, or a monotypic stand instead of a mixed species stand. At the landscape scale, change in forest ecosystem state can be quantified as the area of existing forest types relative to the area of each forest type predicted or expected. Satellite imagery can be used to map forest or other land-cover types to assess changes in forest ecosystems at various scales (Table 1). Forest types that cannot be identified with accuracy using satellite images, usually at fine scales, require more expensive techniques such as aerial photography, LiDAR, or groundtruthing.

\section{Forest fragmentation}

Fragmented forests are degraded because species may be lost and ecosystem processes may be altered or severely disrupted (e.g., Pardini et al. 2010). Land-use change often leads not only to a reduction in forest area but also to the division of remaining forest into patches that may continue to decrease in size over time, creating excessive edges and isolation from continuous habitat (Collinge 1996, Fahrig 2003, Saura and Carballal 2004). At the landscape scale, there are systemspecific and species-specific fragmentation thresholds that, once surpassed, cause significant loss of interior forest species (e.g., Andrén 1994, Santos et al. 2008, Swift and Hannon 2010, Pardini et al. 2010). Sufficient fragmentation may also cause cascading effects on a wide range of ecosystem functions and services (Wu et al. 2003, Diaz et al. 2005). For example, forest fragmentation can reduce carbon storage at the landscape scale (Groeneveld et al. 2009) and can alter hydrological cycles, causing changes in evapotranspiration, local climate, and runoff rates (Ziegler et al. 2007). Fragmentation has significant negative implications for many species, including effects from reduction in total available habitat, reduction in forest interior, increased edge effects, exploitation, and spatial and genetic isolation (Laurance et al. 2000, 2011, Fahrig 2003, Broadbent et al. 2008). Populations of large animals and rare species that prefer forest interiors generally require large areas of contiguous habitat for population persistence and so are especially vulnerable to fragmentation (e.g., Haskell et al. 2002, Cox et al. 2004, Vellend et al. 2006, da Silva and Mendes Pontes 2008, Issac et al. 2009, Thornton et al. 2011). Natural forests that have become increasingly fragmented on a global scale pose a substantial threat to biodiversity (see reviews by Fahrig 2003, Fischer and Lindenmayer 2007).

Fragmentation of forests can be determined from satellite imagery (Table 2) and aerial photography over time. Several metrics can be used to assess fragmentation, and these are available in software such as FRAGSTATS (McGarigal et al. 2012). The value of available fragmentation metrics depends 
on the level of understanding of their relationship to the goods and services of interest. Moreover, to minimize confounding effects, indicators must be compatible with, and interpretable in the light of, information on change in forest area.

\section{Species}

Abundance of species, or groups of species, is used commonly as an indicator for monitoring the effects and effectiveness of forest management (e.g., Oliver and Beattie 1996, Noss 1999, Lewandowski et al. 2010). Many species are sensitive to forest degradation, and numerous examples are available of effects of forest change on species populations (e.g., Lindenmayer et al. 2002, Colles et al. 2009). The choice of species indicator must be made carefully relative to the scale of the effect and with the understanding that other processes may provide alternative hypotheses. Species may be site, stand, or landscape-level indicators depending primarily on their body size and area requirements (e.g., Gardner 2010).

The species approach to indicating forest change has been criticized because of the difficulty in obtaining precise annual population estimates and the high inter-year variability of populations (e.g., Landres et al. 1988, Rolstad et al. 2002). The data requirements may be limiting, both to demonstrate the correlation between species abundance and degradation and to detect changes in populations with statistically valid confidence (Lindenmayer et al. 2002). Therefore, the use of species as indicators requires an understanding of the limitations of the technique. We propose three types of species indicators, including tree species composition, selected focal species (i.e., flagship, umbrella, etc.), and functional species. In all cases, consistent decline in areas affected by humans compared to baseline levels are indicative of degraded forests and the habitats they once supported. For monitoring the multiple processes that together compose degradation, several species (or groups of species representing various trophic levels) indicators may be required.

Tree species composition: The criticisms leveled at species indicators do not apply to plants because they can be easily censused. Achieving a similar tree species composition over time in managed compared with unmanaged stands is an objective of SFM (e.g., Montréal Process 2009). Significant population decline of expected tree species could result in degradation of specific goods and services (e.g., Devi and Behara 2003, Luyssaert et al. 2008) and may indicate a loss of other obligate species associated with particular tree species, such as lichens (e.g., Linder and Östlund 1992). Tree species composition can change as a result of the overharvesting of individual commercially valuable species, or excessive fire (e.g., Devi and Behera 2003, Asner et al. 2006, Foley et al. 2007). Unsustainable harvesting often occurs, particularly in tropical forests, where certain hardwood species are highly sought after, e.g., ipê (Tabebuia spp.; Schulze et al. 2008) and big-leaf mahogany (Swietenia macrophylla;
Kometter et al. 2004, Grogan et al. 2010). Monitoring the tree species composition of a stand over time provides information directly related to ecosystem change.

For humid tropical forest types, where there is high tree species richness at low individual densities, estimates of tree species composition may require that the baseline be defined at the landscape level or by concentrating monitoring on only a few valuable timber species (e.g., Kometter et al. 2004). For more rapid large-area comparisons, remote-sensing techniques are preferred, but only some tree species are identifiable from satellite images (e.g., Carleer and Wolfe 2004, Clark et al. 2005); most species require aerial photography, LiDAR, or ground surveys for identification.

Selected focal species: Many agencies and researchers have successfully used species indicators to monitor ecosystem change because changes in population size or distribution may suggest that habitat abundance or quality have been altered (for esample, McLaren et al. 1998, Festa-Bianchet et al. 2011). Other species are monitored because they are used as game (bushmeat) or are threatened (e.g., Nasi and Frost 2009, Harrison 2011). Hence, data may already be available to enable comparisons over time or against a baseline from a nearby protected area. Species-level monitoring in forests necessarily involves ground or possibly local aerial surveys.

Functional species or groups: Some species are more important than others in providing certain ecosystem functions (e.g., Walker 1992, Díaz et al. 2003), and their loss disproportionately reduces stand processes and the production of certain services (e.g., Díaz and Cabido 2001, Ellison et al. 2005). The loss of highly functional species, in the absence of redundancy (Walker 1992), has negative consequences for ecosystems to the point of ecosystem change or even collapse (Chapin et al. 1997, Ellison et al. 2005). For example, the loss of some or all pollinators would have severe consequences for reproduction by many plants. Some functional species are also keystone species that carry out roles in ecosystems that affect other species such that their loss results in cascading changes (e.g., Terborgh and Estes 2010) and so can indicate forest degradation.

Certain bird, butterfly, or ground beetle assemblages are often used as indicators because of data availability and ease of collection and because many have known functions such as pest reduction and pollination (Lawton et al. 1998). Woodpeckers have been suggested as a forest indicator because of their functional roles as cavity excavators (e.g., Mikuinski and Angelstam 1997, Drever and Martin 2010). Insectivorous birds can regulate insect herbivore populations (Bridgeland et al. 2010), act as seed dispersal agents, and some are pollinators. Many insectivorous birds respond negatively to selective logging and partial harvesting in tropical forests (e.g., Aleixo 1999) and to age composition changes at landscape scales (Yamaura et al. 2009) and so can be used as 
indicators of forest degradation. Bird census methods are widely available but must be carried out in the field.

Pollinators are directly or indirectly related to ecosystem productivity (e.g., Ricketts et al. 2004, Klein et al. 2007), especially in tropical systems (e.g., Samejima et al. 2004). In southeast and east Asia, bees from the genera Micrapis, Magapis, and Apis are particularly useful indicators of forest degradation because they are pollinators of tree flowers and also nest in forests (Oldroyd and Wongsiri 2006, Hepburn and Radloff 2011). Most key pollinators (especially honeybees) require relatively large dead standing trees in which to nest (Seeley and Morse 1976), so the presence of these large snags could be correlated to the presence of bees.

Decomposers in forests help to maintain water and soil quality and promote nutrient cycling (Harris 2009). Microorganisms are important forest decomposers, but little qualitative or quantitative information is available about how they function (e.g., Harris 2003). The soil microbial community is dependent on the level of site disturbance, and therefore, may indicate effects from unsustainable management practices (Harris 2003, 2009). The suite of methods available for developing a monitoring program for decomposers is described by Ritz et al. (2009).

\section{CRITERION 3: UNUSUAL DISTURBANCES}

Extensive unusual disturbances affect the capacity of a forest landscape to supply ecosystem services and reduce resistance to biotic and abiotic stresses (e.g., van Wilgen et al. 2001, Balvanera et al. 2006, Aragão and Shimabukuro 2010). Forest ecosystems are continuously influenced by biotic and abiotic agents at all spatial scales (from individual trees to entire forest types), intensities of impact, and combinations of agents (for example, Attiwill 1994). As long as these disturbances do not exceed the natural variation of an ecosystem over time, they will not cause long-term forest degradation (e.g., Lugo and Scatena 1996, Folke et al. 2004, Thompson et al. 2009). However, some agents may exert severe negative effects to an extent that the original ecosystem changes and the delivery of services is impaired (e.g., van Wilgen et al. 2001, Balvanera et al. 2006). We propose two indicators of specific agents of change, i.e., alien invasive species and fire, both of which have become major causes of forest change in recent decades (e.g., Richardson 1998, Vié et al. 2009, Aragão and Shimabukuro 2010). Arguably, alien invasive species could be considered a biodiversity indicator, but we prefer to separate causes and effects: our biodiversity indicators illustrate effects of forest degradation, whereas invasive species can cause degradation. Other locally important indicators could include native invasive species, incidence of storms, and pest or pathogen outbreaks that are longer and more extensive than normal based on past monitoring.

\section{Indicators of unusual disturbances}

\section{Alien invasive species}

In a given forest type, an invasive alien species is a non-native species that has established a persistent population and is causing harm (Pimentel et al. 2005). Invasive alien species are an important global cause of ecosystem change (e.g., Pejchar and Mooney 2009, Vié et al. 2009), often resulting in a consequent reduction in local biodiversity and ecosystem services (Simberloff et al. 2002, Strayer et al. 2006, Pejchar and Mooney 2009) with economic consequences (Mack et al. 2000, van Wilgen et al. 2001). Globally, many forests have been degraded by invasive alien species (e.g., Chornesky et al. 2005) through mechanisms such as competition, herbivory, disease, or predation (e.g., Lucier et al. 2009). Some forests have been invaded by introduced tree species (Richardson 1998) that have caused ecosystem change. For example, invasive Acacia trees in South Africa are estimated to use up to $10 \%$ of the available water, substantially reducing flows in rivers (van Wilgen et al. 2001, Le Maître et al. 2002). Many invasive tree species occur in, or even dominate, forest canopies and so can been mapped remotely (Table 2). In Hawaiian montane rain forest, Asner and Vitousek (2005) used infrared imaging spectrometry to show that leaf nitrogen concentrations in native Metrosideros polymorpha forests were reduced in areas invaded by Myrica faya. Less obvious invasive tree species must be censused using ground surveys.

Alien invasive insect herbivores such as emerald ash borer (Agrilus planipennis) in eastern North America (http:// emeraldashborer.info/), pests such as pinewood nematode (Bursaphelenchus xylophilus) throughout eastern Asia (Liebhold et al. 1995, Zhao et al. 2008), and alien pathogens such as Dutch elm disease (Ophiostoma ulmi and O. novoulmi) in many areas (Hubbes 1999) have caused degradation over millions of hectares of forests. In most cases and depending on extent, once the cause of damage is known, the area of forest change can be mapped using aerial photographs or satellite imagery (e.g., Pontius et al. 2008). Other invasive species such as ants and earthworms have caused cascading effects over large areas as a result of competition or replacement of endemic species (Kenis et al. 2009, Straube et al. 2009). However, some of these changes may be subtle and difficult to monitor remotely and can only be observed using ground or aerial surveys.

Fire

Human-caused fire is a major cause of forest degradation (for example, Asner et al. 2006), possibly exacerbated by climate warming (e.g., Siegert et al. 2001). An unusual amount of fire can reduce the resilience of ecosystems, resulting in change or loss of ecosystem services (Thompson et al. 2009). Although fire is a natural element in many forest ecosystems, humans have altered fire regimes across $60 \%$ of global terrestrial habitats (Shlisky et al. 2009). Fires have spread in 
extent and frequency in many tropical rainforests with the expansion of agriculture (Uhl and Buschbacher 1985), forest fragmentation, unsustainable shifting cultivation, and logging (Nepstad et al. 1999, Siegert et al. 2001, Alencar et al. 2006). Fire often follows unsustainable logging, resulting in poorquality secondary forests (e.g., Asner et al. 2006). Trees in tropical humid forests are particularly susceptible to fire damage because fires are historically rare (Aragão and Shimabukuro 2010) and the regional flora and fauna are not adapted to such events (Uhl and Kaufmann 1990, Peres et al. $2003 \mathrm{~b}$ ). The loss of natural habitats and species due to excessive fires can cause changes in plant communities and trophic structures within those communities (Dobson et al. 2006, Wright et al. 2007). Fire is likely to increase in the future because of drought associated with global warming (e.g., Siegert et al. 2001). Fires can be quantified by frequency and area burned using satellites (Table 2), especially during or soon after fires because heat or blackened vegetation is readily detected (e.g., Cuomo et al. 2001).

\section{CRITERION 4: PROTECTIVE FUNCTIONS}

Protective functions refer to the intrinsic property of forest ecosystems to maintain soils, soil structure, quality, and moisture levels (e.g., Brandt 1988), which ultimately contribute to forest resilience. Soils play key roles in forest biogeochemical cycles; erosion causes degradation through siltation of watersheds, reduced soil stability, and reduced fertility (Islam et al. 2001, Hartanto et al. 2003, Cotler and Ortega-Larrocea 2006, Neary et al. 2009), and increased rates of rainfall run-off (Lal 1992). Roads cause a disproportionate amount of soil erosion in tropical forests (Dykstra and Heinrich 1992). Vegetation is key to controlling the type and intensity of erosion (e.g., Thornes 1990, Morgan 2005), and eroded soils are often difficult to re-forest (Morgan 2005). Forests play a role in landscape hydrology by regulating water flows through evapotranspiration and infiltration rates (Giambelluca 2002). Although our understanding of this function is not clear with respect to degradation, generally there are more predictable base flows and higher dry season flows from forested areas compared to areas where forest cover has been reduced (e.g., Bruijnzeel 2004, Locatelli and Vignola 2009). We propose two indicators of protective functions: soil erosion and water quantity.

\section{Indicators of protective function}

\section{Soil erosion}

Soil erosion occurs when wind and water translocate soil particles. Although some soil erosion is inevitable through normal precipitation and run-off, it is exacerbated by poor management practices such as inappropriate road placement or timber harvesting methods, especially in areas prone to soil movement such as steep slopes. Stand density plays a large role in avoiding soil erosion (Razafindrabe et al. 2010); for example, forest cover loss in Ghana increased the erosion rate from 1 tonne $\mathrm{ha}^{-1} \mathrm{yr}^{-1}$ to $>100$ tonnes ha ${ }^{-1} \mathrm{yr}^{-1}$ (Repetto 1990). Nutrient loss is a common result of soil erosion. For example, shifting cultivation causes $18-27 \%$ declines in soil carbon, and fallow periods of at least 35 years are required for soils to regain their original carbon content (Detwiler and Hall 1988). The area affected because of soil erosion is the reportable indicator based on remote sensing (Table 2).

\section{Water quantity}

In areas where forest cover is known to help regulate water flow, water levels in rivers and streams among and within years, compared to normal levels, may indicate if sufficient forest cover remains to regulate flows, especially in dry seasons (Bruijnzeel 2004), and in some cases, to prevent flooding (e.g., Douglas et al. 2005). We stress the need for more research on the value of this potential indicator. Flow rates would be taken from field data (Table 1).

\section{CRITERION 5: CARBON STORAGE}

We separated the carbon storage criterion from our production criterion because of current interest in the importance of forests for the global carbon cycle. Approximately $50 \%$ of global terrestrial carbon stocks reside in forest ecosystems as living and dead biomass and soil carbon (Parry et al. 2007, FAO 2010), and forests store an estimated $861 \pm 66 \mathrm{Pg}$ of carbon (Pan et al. 2011). Forest degradation from unsustainable logging, fire, shifting cultivation, and other human-related disturbances can result in substantial reductions in carbon stocks and in the capacity for carbon storage (e.g., Asner et al. 2006, 2009, Foley et al. 2007). Chazdon (2008) suggests a continuum of forest regeneration (in a sense, opposite to degradation) following human disturbances that influences the carbon dynamics in forests. Under this model (see Fig. 2 for an adaptation), the concept that natural and close-to-natural forests store more carbon than degraded forests has been reported for multiple forest types (e.g., Keller et al. 2004, Erskine et al. 2006, Foley et al. 2007, Asner et al. 2009, Chatterjee et al. 2009, Liao et al. 2010, Powers et al. 2011). A hierarchy of degradation effects (Fig. 2) is reinforced by studies showing that primary old-growth forests provide highvalue carbon sinks and will continue to do so for centuries in all forest biomes unless they are disturbed (Phillips et al. 1998, Baker et al. 2004, Luyssaert et al. 2008, Lewis et al. 2009). Forest landscape heterogeneity and fragmentation also influence carbon storage in forests (Numata et al. 2011), suggesting that our fragmentation indicator may also correlate with carbon storage. Forest degradation reduces future biomass accumulation by causing a shift in species composition, tree size structure, tree species richness, and abundance of lianas (Asner et al. 2006, Foley et al. 2007, Russell et al. 2010). We propose two indicators: total carbon stored and populations of high wood-density trees. 
Fig. 2. Degradation is a continuum of decline in ecosystem goods and services from primary forest to deforested lands. This continuum is illustrated for a generalized dry closed tropical forest. Biodiversity refers to species richness and ecosystem type richness relative to a baseline. Ecosystem services refers to services related directly to biodiversity such as pollination and biomass production. Sustainably managed forests are shown close to, but slightly below, primary forests based on multiple studies (e.g., Asner at al. 2006, Lewis 2009, Klimes et al. 2012; Putz et al. 2012).

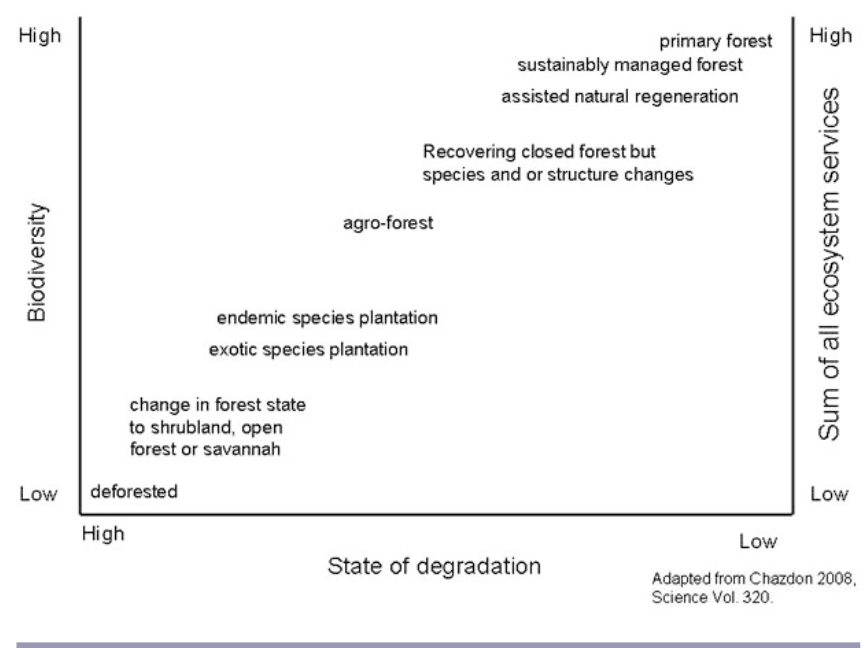

\section{Indicators of carbon storage}

\section{Stored carbon}

Methods and tools are available for estimating forest carbon stocks, with default values, including biomass functions and/ or conversion factors, available for different carbon pools and ecological zones (IPCC 2006, Herold et al. 2011b). Several studies have used satellites and other techniques to map carbon density (Table 2). Nevertheless, remote-sensing tools for biomass estimation still require ground corroboration in many cases to improve the accuracy and precision of carbon estimates (e.g., Herold et al. 2011a). Ground census work will improve estimates from models, especially for fallen dead wood, belowground carbon, and sub-canopy structure (e.g., Goetz et al. 2009, Bryan et al. 2010, Eckert et al. 2011).

\section{High wood-density tree species}

Tree growth rates and accumulated wood fiber biomass represent changes in the aboveground carbon sink. For the same size of tree, dense-wood species store more carbon than do trees with less-dense wood (e.g., Chave et al. 2006, Russell et al. 2010, Potvin et al. 2011). Although there is only an incomplete understanding of the relationship between carbon sequestration and tree species and among carbon sequestration, forest management, and disturbance, some tree species require more carbon than others during growth, usually grow slowly, and ultimately store more carbon for a long period (e.g., Bunker et al. 2005, Vieira et al. 2005, Russell et al. 2010, Sharma et al. 2010). As a result, forests may be degraded in terms of the carbon stored if tree diversity is reduced, for example, through excessive selective logging of high wood-density tree species such as mahogany (Kirby and Potvin 2007). Hence, monitoring populations of high wooddensity tree species over time relative to an expected population (by age class) can indicate forest ecosystem degradation (see stand-scale ecosystem diversity and biomass indicators, above) with respect to carbon storage over the long term (e.g., Vieira et al. 2005). Monitoring for individual trees would necessarily be at the stand level from aircraft or ground plots.

\section{MINIMUM SET OF INDICATORS}

As previously suggested, what constitutes forest degradation is often related to local perception and societal choice. Nevertheless, to understand fully how ecosystem services might have been reduced or lost, and especially under an ecosystem management regime, each of the five criteria should be reported to quantify types of degradation. To accomplish this, we suggest that a minimum subset of seven indicators should be monitored (Table 1). These seven indicators were selected based on the need for at least one indicator from each criterion, the current capability to measure the indicator using remote sensing, the existence of data to enable trend analysis in many parts of the world, and the direct linkage to regional and global reporting processes (e.g., CBD and SFM). The indicators can be compiled as a percentage deviation from the baseline and portrayed graphically (e.g., Fig. 3). This diagram maintains the strength of the individual indicators and also provides a graphical representation emulating a single composite index (e.g., Bahamóndez et al. 2007, 2010). Graphical representation easily enables managers to see the relative contribution by types degradation that are affecting their forests.

\section{Measurement frequency}

We suggest that 3 to 5 years should be a sufficient monitoring interval to allow enough time for change to occur for most indicators. It may be necessary, however, to monitor selected individual species more frequently because of potential rapid population change. In the cases of tree species richness, ecosystem diversity, and fragmentation, change is often much slower than for the other indicators; these indicators may only require monitoring every 5 years or more to observe a trend.

\section{DISCUSSION}

Forest degradation is a topic of global concern because of the loss of goods and services, the emission of greenhouse gases, and problematic restoration. Clearly, what is of greatest concern is the long-term, large-scale degradation of forests (for example, ITTO 2002), especially when the ecosystem has 
changed states and is severely degraded. Although many definitions of forest degradation converge on the loss of ecosystem services (Simula 2009), no previous operational guidance has been available to help define degradation. We have proposed five types of forest degradation that represent a continuum of reduction in the supply of goods and services compared to pre-defined reference values. Recognizing that most ecosystem services can be measured provides a means to quantify the extent and progression of degradation (e.g., van Wilgen et al. 2001, TEEB 2009, Thompson et al. 2011).

Fig. 3. A schematic composite diagram proposed as a visual illustration of the multiple types of forest degradation. The interior solid red line represents scoring for each of the five criteria on scales for the indicators relevant to the forest type or region, as a percentage (dashed lines) of the desired or predicted baseline values. The diagram can be used for stand to landscape and sub-national level data and so is applicable for any scale of interest.

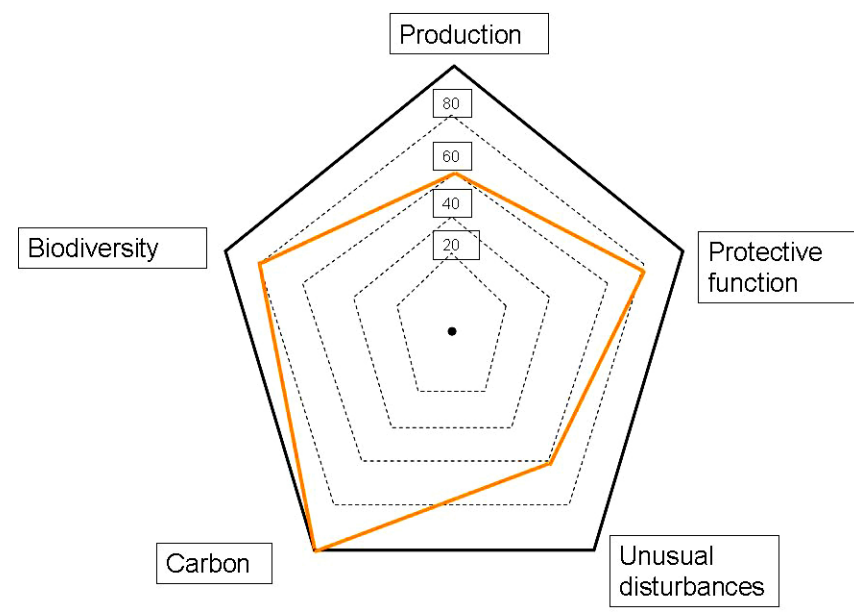

We suggest that criteria indicating changes in production, biodiversity, protective functions, unusual disturbances, and carbon storage will enable assessment of the amount and type of degradation (Fig. 3). The proposed criteria and indicators framework provides a means to distinguish among levels (for example, light to severe) of degradation and to reconcile among multiple perspectives. To use the criteria rigorously, agencies should decide a priori whether all or certain of the criteria are of interest. Most countries that currently report to the UN Food and Agriculture Organization on forests and to other intergovernmental forest-related organizations on forest processes (e.g., ITTO) already report on some of our proposed indicators. Nevertheless, all of the criteria should be applied to describe degradation where ecosystem sustainability is the forest objective.

Under the REDD mechanism of the UNFCCC, it will be necessary, in part, to identify a degraded forest to implement some projects. Our approach provides a way to define forests that are degraded and can also enable specific focus, for recovery, on the key services that are most degraded. It is also important that reporting on degradation be understood in context with planned land management, where it exists. For example, much of the work on past selective logging in a landuse change context has been concerned with quantitative assessment using remote sensing techniques (e.g., Asner et al. 2006, Matricardi et al. 2010). Hence, such studies may not distinguish unsustainable logging from SFM guided by an approved plan (see, e.g., Foley et al. 2007 and commentary by Peña-Claros et al. 2007 and Putz et al. 2007). Distinguishing between forest degradation and well-managed regenerating forests is essential for reporting and project planning.

\section{Challenges to implementation}

Determining the range of natural variation for some of the indicators presents a major challenge. The task is easier, however, if unmanaged or sustainably managed forest is available as a benchmark, than for situations where general models must be used to establish baseline values (e.g., IPCC 2006). A further challenge for managers is to develop an effective monitoring program and maintain it over time to determine changes in the forests at large and/or local scales. Priority should be placed on improving skills and institutions, as these are ultimately the building blocks of effective forest management (Sheil et al. 2004, Nasi and Frost 2009).

It is important that the selected species or species groups do indeed indicate habitat quality and quantity (e.g., Niemi et al. 1997), and problems with obtaining statistically useful results are a concern (e.g., Rolstad et al. 2002). Indicator species analysis is a key way forward in the use of species indicators as analytical tools (e.g., Bakker 2008). Gardner et al. (2012) suggested a tiered approach to the use of indicators based on data quality and scale. This approach could be taken for monitoring degradation with progressive refinements to scale occurring over time as databases for indicators improve. Expert judgment remains the foundation of competent species selection, but improved data and expertise can inform this judgment.

Finally, once degraded forests have been delineated, recovering these areas to fully functioning forest ecosystems requires energy input and considerable planning (e.g., Mack et al. 2000), especially if the ecosystem has changed states. Forest managers and stakeholders may have to decide the level or amount of degradation that they are willing to accept across a landscape because trade-offs will often exist among management objectives (e.g., Lamb 1998, Thompson et al. 2011). Further, deciding how to allocate funds for forest recovery is not an easy task (Holl and Aide 2011). Once assessments have been accomplished to define degraded areas, their type, and level of degradation, considerable planning will be required to place areas into categories rated for relative ease and investment needed for recovery, with management 
restoration plans devised and targets set against which to measure success in an adaptive manner (see, e.g., Lamb et al. 2005). Fortunately, comprehensive guidance for recovering or restoring degraded tropical forest areas can be found in ITTO (2002).

Responses to this article can be read online at: http://www.ecologyandsociety.org/issues/responses. php/5443

\section{Acknowledgments:}

We thank the United Nations FAO Forestry Department and especially M. Loiche-Wilkie for securing funding for two expert group meetings to discuss indicators of degradation. IDT was supported by, and worked on behalf of, the Secretariat to the Convention on Biological Diversity. MRG and RN were supported by the CGIAR Research Program, "Forests, Trees and Agroforestry: Livelihoods, Landscapes and Governance". $K O$ was partly supported by the Global Environment Research Fund (S9). Valerie Kapos and two anonymous reviewers assisted in improving the manuscript.

\section{LITERATURE CITED}

Achard, F., H. D. Eva, H.-J. Stibig, P. Mayaux, J. Gallego, T. Richards, and J.-P. Mallingreau. 2002. Determination of deforestation rates of the world's humid tropical forests. Science 297:999-1002. http://dx.doi.org/10.1126/science.1070656

Ahrends, A., N. D. Burgess, S. A. H. Milledge, M. T. Bulling, B. Fisher, J. C. R. Smart, G. P. Clarke, B. E. Mhoro, and S. L. Lewis. 2010. Predictable waves of sequential forest degradation and biodiversity loss spreading from an African city. Proceedings of the National Academy of Sciences 107 (33):14556-14561. http://dx.doi.org/10.1073/pnas.0914471107

Aleixo, A. 1999. Effects of selective logging on a bird community in the Brazilian Atlantic forest. Condor 101 (3):537-548. http://dx.doi.org/10.2307/1370183

Alencar, A., D. Nepstad, and M. C. V. Diaz. 2006. Forest understory fire in the Brazilian Amazon in ENSO and nonENSO years: area burned and committed carbon emissions. Earth Interactions 10(6):1-17. http://dx.doi.org/10.1175/ EI150.1

Allen, T. F. H., and T. W. Hoekstra. 1992. Toward a unified ecology. Columbia University Press, New York, New York, USA.

Andrén, H. 1994. Effects of habitat fragmentation on birds and mammals in landscapes with different proportions of suitable habitat: a review. Oikos 71(3):355-366. http://dx.doi. org $/ 10.2307 / 3545823$
Aragão, L. E. O. C., and Y. E. Shimabukuro. 2010. The incidence of fire in Amazonian forests with implications for REDD. Science 328:1275-1278. http://dx.doi.org/10.1126/ science. 1186925

Asner, G. P., E. N. Broadbent, P. J. C. Oliveira, M. Keller, D. E. Knapp, and J. N. M. Silva. 2006. Condition and fate of logged forests in the Brazilian Amazon. Proceedings of the National Academy of Sciences 103(34):12947-12950. http:// dx.doi.org/10.1073/pnas.0604093103

Asner, G. P., R. F. Hughes, P. M. Vitousek, D. E. Knapp, T. Kennedy-Bowdoin, J. Boardman, R. E. Martin, M. Eastwood, and R. O. Green. 2008. Invasive plants transform the threedimensional structure of rain forests. Proceedings of the National Academy of Sciences 105(11):4519-4523. http://dx. doi.org/10.1073/pnas.0710811105

Asner, G. P., D. E. Knapp, A. Balaji, and G. Paez-Acosta. 2009. Automated mapping of tropical deforestation and forest degradation: CLASlite. Journal of Applied Remote Sensing 3 (1): 033543. http://dx.doi.org/10.1117/1.3223675

Asner, G. P., and P. M. Vitousek. 2005. Remote analysis of biological invasion and biogeochemical change. Proceedings of the National Academy of Sciences 102(12):4383-4386. http://dx.doi.org/10.1073/pnas.0500823102

Attiwill, P. M. 1994. The disturbance of forest ecosystems: the ecological basis for conservative management. Forest Ecology and Management 63(2-3):247-300. http://dx.doi. org/10.1016/0378-1127(94)90114-7

Baccini, A., S. J. Goetz, W. S. Walker, N. T. Laporte, M. Sun, D. Sulla-Menashe, J. Hackler, P. S. A. Beck, R. Dubayah, M. A. Friedl, S. Samanta, and R. A. Houghton. 2012. Estimated carbon dioxide emissions from tropical deforestation improved by carbon-density maps. Nature Climate Change 2:182-185. http://dx.doi.org/10.1038/nclimate1354

Bahamóndez, C., P. A. Jofré, M. C. Martin, S. Müller-Using, A. V. Pugin, Y. V. Rojas, S. Barros. 2010. Reporte de sustentabilidad de los ecosistemas forestales nativos regiones del Maule a Magallanes. Technical Report 180. Instituto Forestal, Santiago, Chile. [online] URL: http://biblioteca1. infor.cl:81/ficha.asp?param=0\%AD\%88\%92bi\%96\%8Fnf.

Bahamóndez, C., M. C. Martin, S. Müller-Using, O. Peña, A. V. Pugin, Y. V. Rojas, M. A. Stange, M. Uribe, and G. E. Vergara. 2007. Inventario de los Bosques de Alerce. Final Report. Instituto Forestal, Valdivia, Chile. [online] URL: http://bibliotecal.infor.cl:81/ficha.asp?param=0\%AD\%88\%92bi\% 95\%88se.

Bahamóndez, C., M. Martin, S. Müller-Using, Y. Rojas, and G. Vergara. 2009. Case studies on measuring and assessing forest degradation: an operational approach to forest degradation. Forest Resources Assessment Working Paper 
158. FAO, Rome, Italy. [online] URL: http://www.fao.org/ docrep/012/k7177e/k7177e00.pdf.

Baker, T. R., O. L. Phillips, Y. Malhi, S. Almeida, L. Arroyo, A. Di Fiore, T. Erwin, N. Higuchi, T. J. Killeen, S. G. Laurance, W. F. Laurance, S. L. Lewis, A. Monteagudo, D. A. Neill, P. Núñez Vargas, N. C. A. Pitman, J. N. M. Silva, and R. Vásquez Martínez. 2004. Increasing biomass in Amazonian forest plots. Philosophical Transactions of the Royal Society of London B 359(1443):353-365. http://dx.doi.org/10.1098/rstb.2003.1422

Bakker, J. D. 2008. Increasing the utility of indicator species analysis. Journal of Applied Ecology 45(6):1829-1835. http:// dx.doi.org/10.1111/j.1365-2664.2008.01571.x

Balvanera, P., A. B. Pfisterer, N. Buchmann, J.-S. He, T. Nakashizuka, D. Raffaelli, and B. Schmid. 2006. Quantifying the evidence for biodiversity effects on ecosystem functioning and services. Ecology Letters 9(10):1146-1156. http://dx.doi. org/10.1111/j.1461-0248.2006.00963.x

Brandt, J. 1988. The transformation of rainfall energy by a tropical rain forest canopy in relation to soil erosion. Journal of Biogeography 15(1):41-48. http://dx.doi.org/10.2307/2845044

Bridgeland, W. T., P. Beier, T. Kolb, and T. G. Whitham. 2010. A conditional trophic cascade: birds benefit faster growing trees with strong links between predators and plants. Ecology 91(1):73-84. http://dx.doi.org/10.1890/08-1821.1

Broadbent, E. N., G. P. Asner, M. Keller, D. E. Knapp, P. J. C. Oliveira, and J. N. Silva. 2008. Forest fragmentation and edge effects from deforestation and selective logging in the Brazilian Amazon. Biological Conservation 141(7):1745-1757. http://dx.doi.org/10.1016/j.biocon.2008.04.024

Brockerhoff, E. G., H. Jactel, J. A. Parrotta, C. P. Quine, and J. Sayer. 2008. Plantation forests and biodiversity: oxymoron or opportunity? Biodiversity and Conservation 17 (5):925-951. http://dx.doi.org/10.1007/s10531-008-9380-x

Bruijnzeel, L. A. 2004. Hydrological functions of tropical forests: not seeing the soil for the trees? Agriculture, Ecosystems and Environment 104(1):185-228. http://dx.doi. org/10.1016/j.agee.2004.01.015

Bryan, J., P. Shearman, J. Ash, and J. B. Kirkpatrick. 2010. Estimating rainforest biomass stocks and carbon loss from deforestation and degradation in Papua New Guinea 19722002: best estimates, uncertainties and research needs. Journal of Environmental Management 91(4):995-1001. http://dx.doi. org/10.1016/j.jenvman.2009.12.006

Bunker, D. E., F. DeClerck, J. C. Bradford, R. K. Colwell, I. Perfecto, O. L. Phillips, M. Sankaran, and S. Naeem. 2005. Species loss and aboveground carbon storage in a tropical forest. Science 310:1029-1031. http://dx.doi.org/10.1126/ science. 1117682
Carleer, A., and E. Wolfe. 2004. Exploitation of very high resolution satellite data for tree species identification. Photogrammetric Engineering and Remote Sensing 70:135-140.

Chapin, F. S., III, B. H. Walker, R. J. Hobbs, D. U. Hooper, J. H. Lawton, O. E. Sala, and D. Tilman. 1997. Biotic control over the functioning of ecosystems. Science 277:500-504. http://dx.doi.org/10.1126/science.277.5325.500

Chatterjee, A., G. F. Vance, and D. B. Tinker. 2009. Carbon pools of managed and unmanaged stands of ponderosa and lodgepole pine forests in Wyoming. Canadian Journal of Forest Research 39(10):1893-1900. http://dx.doi.org/10.1139/ $\underline{\mathrm{X} 09-112}$

Chave, J., H. C. Muller-Landau, T. R. Baker, T. A. Easdale, H. ter Steege, and C. O. Webb. 2006. Regional and phylogenetic variation of wood density across 2456 neotropical tree species. Ecological Applications 16 (6):2356-2367. http://dx.doi.org/10.1890/1051-0761(2006) 016[2356:RAPVOW]2.0.CO;2

Chazdon, R. L. 2008. Beyond deforestation: restoring forests and ecosystem services on degraded lands. Science 320:1458-1460. http://dx.doi.org/10.1126/science.1155365

Chornesky, E. A., A. M. Bartuska, G. H. Aplet, K. O. Britton, J. Cummings-Carlson, F. W. Davis, J. Eskow, D. R. Gordon, K. W. Gottschalk, R. A. Haack, A. J. Hansen, R. N. Mack, F. J. Rahel, M. A. Shannon, L. A. Wainger, and T. B. Wigley. 2005. Science priorities for reducing the threat of invasive species to sustainable forestry. BioScience 55(4):335-348. http://dx.doi.org/10.1641/0006-3568(2005)055[0335:SPFRTT] 2.0.CO;2

Clark, M. L., D. A. Roberts, and D. B. Clark. 2005. Hyperspectral discrimination of tropical rain forest tree species at leaf to crown scales. Remote Sensing of Environment 96(3-4):375-398. http://dx.doi.org/10.1016/j.rse.2005.03.009

Colles, A., L. H. Liow, and A. Prinzig. 2009. Are specialists at risk under environmental change? Neoecological, paleoecological and phylogenetic approaches. Ecology Letters 12(8):849-863. http://dx.doi.org/10.1111/

j.1461-0248.2009.01336.x

Collinge, S. K. 1996. Ecological consequences of habitat fragmentation: implications for landscape architecture and planning. Landscape and Urban Planning 36(1):59-77. http:// dx.doi.org/10.1016/S0169-2046(96)00341-6

Convention on Biological Diversity. 2010. COP10 Decision X/2. Strategic plan for biodiversity 2011-2020. [online] URL: http://www.cbd.int/decision/cop/?id=12268.

Cotler, H., and M. P. Ortega-Larrocea. 2006. Effects of land use on soil erosion in a tropical dry forest ecosystem, Chamela 
watershed, Mexico. Catena 65(2):107-117. http://dx.doi. org/10.1016/j.catena.2005.11.004

Cox, M. P., C. R. Dickman, and J. Hunter. 2004. Effects of rainforest fragmentation on non-flying mammals of the Eastern Dorrigo Plateau, Australia. Biological Conservation 115(2):175-189. http://dx.doi.org/10.1016/S0006-3207(03) 00105-8

Cuomo, V., R. Lasaponara, and V. Tramutoli. 2001. Evaluation of a new satellite-based method for forest fire detection. International Journal of Remote Sensing 22 (9):1799-1826. http://dx.doi.org/10.1080/01431160120827

da Silva, A. P., Jr., and A. R. Mendes Pontes. 2008. The effect of a mega-fragmentation process on large mammal assemblages in the highly-threatened Pernambuco Endemism Centre, north-eastern Brazil. Biodiversity and Conservation 17(6):1455-1464. http://dx.doi.org/10.1007/s10531-008-9353-0

DeFries, R., F. Achard, S. Brown, M. Herold, D. Murdiyarso, B. Schlamadinger, and C. de Souza, Jr. 2006. Reducing greenhouse gas emissions from deforestation in developing countries: considerations for monitoring and measuring. GOFC-GOLD report 26. GTOS report 46. Global Terrestrial Observing System Secretariat, FAO, Rome, Italy. [online] URL: http://www.fao.org/gtos/doc/pub46.pdf.

Dennis, R. A., and C. P. Colfer. 2006. Impacts of land use and fire on the loss and degradation of lowland forest in 19832000 in East Kutai District, East Kalimantan, Indonesia. Singapore Journal of Tropical Geography 27(1):30-48. http:// dx.doi.org/10.1111/j.1467-9493.2006.00238.x

Detwiler, R. P., and C. A. S. Hall. 1988. Tropical forests and the global carbon cycle. Science 239:42-47. http://dx.doi. org/10.1126/science.239.4835.42

Devi, U., and N. Behera. 2003. Assessment of plant diversity in response to forest degradation in a tropical dry deciduous forest of Eastern Ghats in Orissa. Journal of Tropical Forest Science 15(1):147-163.

Díaz, S., and M. Cabido. 2001. Vive la différence: plant functional diversity matters to ecosystem processes. Trends in Ecology and Evolution 16(11):646-655. http://dx.doi. org/10.1016/S0169-5347(01)02283-2

Díaz, S., A. J. Symstad, F. S. Chapin III, D. A. Wardle, and L. F. Huenneke. 2003. Functional diversity revealed by removal experiments. Trends in Ecology and Evolution 18 (3):140-146. http://dx.doi.org/10.1016/S0169-5347(03)00007-7

Diaz, S., D. Tilman, J. Fargione, F. S. Chapin, R. Dirzo, T. Kitzberger, B. Gemmill, M. Zobel, M. Vila, C. Mitchell, A. Wilby, G. C. Daly, M. Galetti, W. F. Laurence, J. Pretty, R. Naylor, A. Power, D. Harvell, S. Potts, C. Kremen, T. Griswold, and C. Eardley. 2005. Biodiversity regulation of ecosystem services. Pages 299-329 in R. Hassan, R. Scholes, and N. Ash, editors. Ecosystems and human well-being: current state and trends, volume 1. Island Press, Washington, D.C., USA.

Dobson, A., D. Lodge, J. Alder, G. S. Cumming, J. Keymer, J. McGlade, H. Mooney, J. A. Rusak, O. Sala, V. Wolters, D. Wall, R. Winfree, and M. A. Xenopoulos. 2006. Habitat loss, trophic collapse, and the decline of ecosystem services. Ecology 87(8):1915-1924. http://dx.doi.org/10.1890/0012-9658 (2006)87[1915:HLTCAT]2.0.CO;2

Douglas, E. M., K. Sebastian, C. J. Vorosmarty, S. Wood, and K. M. Chomitz. 2005. The role of tropical forests in supporting biodiversity and hydrological integrity. World Bank Policy Research Working Paper 3635. World Bank, Washington, D. C., USA. [online] URL: http://ssrn.com/abstract=757186. http://dx.doi.org/10.2139/ssrn.757186

Drever, M. C., and K. Martin. 2010. Response of woodpeckers to changes in forest health and harvest: implications for conservation of biodiversity. Forest Ecology and Management 259(5):958-966. http://dx.doi.org/10.1016/j.foreco.2009.11.038

Dykstra, D. P., and R. Heinrich. 1992. Sustaining tropical forests through environmentally sound harvesting practices. Unasylva 169 43:9-15.

Eckert, S., H. R. Ratsimba, L. O. Rakotondrasoa, L. G. Rajoelison, and A. Ehrensperger. 2011. Deforestation and forest degradation monitoring and assessment of biomass and carbon stock of lowland rainforest in the Analanjirofo region, Madagascar. Forest Ecology and Management 262 (11):1996-2007. http://dx.doi.org/10.1016/j.foreco.2011.08.041

Edwards, D. P., T. H. Larsen, T. D. S. Docherty, F. A. Ansell, W. W. Hsu, M. A. Derhé, K. C. Hamer, and D. S. Wilcove. 2011. Degraded lands worth protecting: the biological importance of Southeast Asia's repeatedly logged forests. Proceedings of the Royal Society B 278(1702):82-90. http:// dx.doi.org/10.1098/rspb.2010.1062

Ellison, A. M., M. S. Bank, B. D. Clinton, E. A. Colburn, K. Elliott, C. R. Ford, D. R. Foster, B. D. Kloeppel, J. D. Knoepp, G. M. Lovett, J. Mohan, D. A. Orwig, N. L. Rodenhouse, W. V. Sobczak, K. A. Stinson, J. K. Stone, C. M. Swan, J. Thompson, B. Von Holle, and J. R. Webster. 2005. Loss of foundation species: consequences for the structure and dynamics of forested ecosystems. Frontiers in Ecology and Environment 3(9):479-486. http://dx.doi.org/10.1890/1540-9295 (2005)003[0479:LOFSCF]2.0.CO;2

Erskine, P. D., D. Lamb, and M. Bristow. 2006. Tree species diversity and ecosystem function: Can tropical multi-species plantations generate greater productivity? Forest Ecology and Management 233(2-3):205-210. http://dx.doi.org/10.1016/j. foreco.2006.05.013 
Everitt, J. H., and C. J. Deloach. 1990. Remote sensing of Chinese tamarisk (Tamarix chinensis) and associated vegetation. Weed Science 38(3):273-278.

Fahrig, L. 2003. Effects of habitat fragmentation on biodiversity. Annual Review of Ecology and Systematics 34:487-515. http://dx.doi.org/10.1146/annurev.

\section{ecolsys.34.011802.132419}

FAO (Food and Agriculture Organization). 2001. Global ecological zoning for the global forest resources assessment 2000. Forestry Working Paper 56. Food and Agriculture Organization, Rome, Italy. [online] URL: ftp://ftp.fao.org/ docrep/fao/006/ad652e/ad652e00.pdf.

FAO (Food and Agriculture Organization). 2002. Directrices prácticas para la evaluación, medición, aplicación y seguimiento de los criterios e indicadores, a nivel nacional, para la ordenación sostenible de los bosques de Centro América. Food and Agriculture Organization, Rome, Italy. [online] URL: http://agendaforestal.org/documentos/Directrices\% 20Lepaterique\%20Version\%20Final\%20.pdf; English summary: http://www.fao.org/docrep/004/AC135E/ac135e07.htm.

FAO (Food and Agriculture Organization). 2005. Global forest resources assessment. Food and Agriculture Organization, Rome, Italy. [online] URL: http://www.fao.org/ forestry/fra2005.

FAO (Food and Agriculture Organization). 2010. Global forest resources assessment 2010. FAO Forestry Paper 163. Food and Agriculture Organization, Rome, Italy. [online] URL: http://www.fao.org/docrep/013/i1757e/i1757e.pdf.

Ferreira, M. T., F. C. Aguiar, and C. Nogueira. 2005. Changes in riparian woods over space and time: influence of environment and land use. Forest Ecology and Management 212(1):145-159. http://dx.doi.org/10.1016/j.foreco.2005.03.010

Festa-Bianchet, M., J. C. Ray, S. Boutin, S. D. Côté, and A. Gunn. 2011. Conservation of caribou (Rangifer tarandus) in Canada: an uncertain future. Canadian Journal of Zoology 89:419-434. http://dx.doi.org/10.1139/z11-025

Fischer, J., and D. B. Lindenmayer. 2007. Landscape modification and habitat fragmentation: a synthesis. Global Ecology and Biogeography 16(3):265-280. http://dx.doi. org/10.1111/j.1466-8238.2007.00287.x

Foley, J. A., G. P. Asner, M. H. Costa, M. T. Coe, R. DeFries, H. K. Gibbs, E. A. Howard, S. Olson, J. Patz, N. Ramankutty, and P. Snyder. 2007. Amazonia revealed: forest degradation and loss of ecosystem goods and services in the Amazon basin. Frontiers in Ecology and the Environment 5(1):25-32. http:// dx.doi.org/10.1890/1540-9295(2007)5[25:ARFDAL]2.0.CO;2

Folke, C., S. Carpenter, B. Walker, M. Scheffer, T. Elmqvist, L. Gunderson, and C. S. Holling. 2004. Regime shifts, resilience, and biodiversity in ecosystem management. Annual
Review of Ecology, Evolution, and Systematics 35:557-581. http://dx.doi.org/10.1146/annurev.ecolsys.35.021103.105711

Gallaun, H., G. Zanchi, G.-J. Nabuurs, G. Hengeveld, M. Schardt, and P. J. Verkerk. 2010. EU-wide maps of growing stock and above-ground biomass in forests based on remote sensing and field measurements. Forest Ecology and Management 260:252-261. http://dx.doi.org/10.1016/j. foreco.2009.10.011

Gardner, T. A. 2010. Monitoring forest biodiversity: improving biodiversity conservation through ecologically responsible management. Earthscan, London, UK.

Gardner, T. A., N. D. Burgess, N. Aguilar-Amuchastegui, J. Barlow, E. Berenguer, T. Clements, F. Danielsen, J. Ferreira, W. Foden, V. Kapos, S. M. Khan, A. C. Lees, L. Parry, R. M. Roman-Cuesta, C. B. Schmitt, N. Strange, I. Theilade, and I. C. G. Vieira. 2012. A framework for integrating biodiversity concerns into national REDD+ programmes. Biological Conservation 154:61-71. http://dx.doi.org/10.1016/j.

biocon.2011.11.018

Giambelluca, T. W. 2002. Hydrology of altered tropical forest. Hydrological Processes 16(8):1665-1669. http://dx.doi. org/10.1002/hyp.5021

Girard, P. 2002 Charcoal production and use in Africa: what future? Unasylva 211 53:30-35.

Goetz, S. J., A. Baccini, N. T. Laporte, T. Johns, W. Walker, J. Kellndorfer, R. A. Houghton, and M. Sun. 2009. Mapping and monitoring carbon stocks with satellite observations: a comparison of methods. Carbon Balance and Management 4: 2. http://dx.doi.org/10.1186/1750-0680-4-2

Groeneveld, J., L. F. Alves, L. C. Bernacci, E. L. M. Catharino, C. Knogge, J. P. Metzger, S. Pütz, and A. Huth. 2009. The impact of fragmentation and density regulation on forest succession in the Atlantic rain forest. Ecological Modelling 220(19):2450-2459. http://dx.doi.org/10.1016/j.

ecolmodel.2009.06.015

Grogan, J., A. G. Blundell, R. M. Landis, A. Youatt, R. E. Gullison, M. Martinez, R. Kómetter, M. Lentini, and R. E. Rice. 2010. Over-harvesting driven by consumer demand leads to population decline: big-leaf mahogany in South America. Conservation Letters 3(1):12-20. http://dx.doi. org/10.1111/j.1755-263X.2009.00082.X

Gunderson, L. H. 2000. Ecological resilience: in theory and application. Annual Review of Ecology, Evolution and Systematics 31:425-439. http://dx.doi.org/10.1146/annurev. ecolsys.31.1.425

Harper, G. J., M. K. Steininger, C. J. Tucker, D. Juhn, and F. Hawkins. 2007. Fifty years of deforestation and forest fragmentation in Madagascar. Environmental Conservation 34(4):325-333. http://dx.doi.org/10.1017/S0376892907004262 
Harris, J. A. 2003. Measurement of the soil microbial community for estimating the success of restoration. European Journal of Soil Science 54(4):801-808. http://dx.doi. org/10.1046/j.1351-0754.2003.0559.x

Harris, J. A. 2009. Soil microbial communities and restoration ecology: facilitators or followers? Science 325:573-574. http://dx.doi.org/10.1126/science.1172975

Harrison, R. D. 2011. Emptying the forest: hunting and the extirpation of wildlife from tropical nature reserves. BioScience 61(11):919-924. http://dx.doi.org/10.1525/ bio.2011.61.11.11

Hartanto, H., R. Prabhu, A. S. E. Widayat, and C. Asdak. 2003. Factors affecting runoff and soil erosion: plot-level soil loss monitoring for assessing sustainability of forest management. Forest Ecology and Management 180(1):361-374. http://dx. doi.org/10.1016/S0378-1127(02)00656-4

Haskell, J. P., M. E. Ritchie, and H. Olff. 2002. Fractal geometry predicts varying body size scaling relationships for mammal and bird home ranges. Nature 418(6897):527-530. http://dx.doi.org/10.1038/nature00840

Hepburn, H. R., and S. E. Radloff, editors. 2011. Honeybees of Asia. Springer, Berlin, Germany. http://dx.doi. org/10.1007/978-3-642-16422-4

Herold, M., R. M. Román-Cuesta, V. Heymell, Y. Hirata, P. Van Laake, G. P. Asner, C. Souza, V. Avitabile, and K. MacDicken. 2011a. A review of methods to measure and monitor historical carbon emissions from forest degradation. Unasylva 238 62:16-24.

Herold, M., R. M. Román-Cuesta, D. Mollicone, Y. Hirata, P. van Laake, G. P. Asner, C. Souza, M. Skutsch, V. Avitabile, and K. MacDicken. 2011b. Options for monitoring and estimating historical carbon emissions from forest degradation in the context of REDD+. Carbon Balance and Management 6: 13. [online] URL: http://www.cbmjournal.com/content/ pdf/1750-0680-6-13.pdf. http://dx.doi.org/10.1186/1750-0680-6-13

Holl, K. D., and T. M. Aide. 2011. When and where to actively restore ecosystems? Forest Ecology and Management 261 (10):1558-1563. http://dx.doi.org/10.1016/j.foreco.2010.07.004

Hollaus, M., W. Wagner, K. Schadauer, B. Maier, and K. Gabler. 2009. Growing stock estimation for alpine forests in Austria: a robust Lidar-based approach. Canadian Journal of Forest Research 39(7):1387-1400. http://dx.doi.org/10.1139/ $\underline{\mathrm{X} 09-042}$

Hubbes, M. 1999. The American elm and Dutch elm disease. Forestry Chronicle 75(2):265-273.

Huettner, M., R. Leemans, K. Kok, and J. Ebeling. 2009. A comparison of baseline methodologies for 'Reducing Emissions from Deforestation and Degradation'. Carbon Balance and Management 4: 4. [online] URL: http://www. cbmjournal.com/content/4/1/4. http://dx.doi.org/10.1186/17$\underline{\text { 50-0680-4-4 }}$

IPCC (Intergovernmental Panel on Climate Change). 2006. 2006 IPCC guidelines for national greenhouse gas inventories. Institute for Global Environmental Strategies, Hayama, Japan. [online] URL: http://www.ipcc-nggip.iges. or.jp/public/2006gl/.

Islam, K. R., M. R. Ahmed, M. K. Bhuiyan, and A. Badruddin. 2001. Deforestation effects on vegetative regeneration and soil quality in tropical semi-evergreen degraded and protected forests of Bangladesh. Land Degradation and Development 12(1):45-56. http://dx.doi.org/10.1002/ldr.418

Issac, J. L., J. Vanderwal, C. N. Johnson, and S. E. Williams. 2009. Resistance and resilience: quantifying relative extinction risk in a diverse assemblage of Australian tropical rainforest vertebrates. Diversity and Distributions 15 (2):280-288. http://dx.doi.org/10.1111/j.1472-4642.2008.00531. $\underline{x}$

ITTO (International Tropical Timber Organization). 2002. ITTO Guidelines for the restoration, management and rehabilitation of degraded and secondary tropical forests. ITTO Policy Development Series 13. ITTO, Yokohama, Japan. [online] URL: http://www.itto.int/direct/topics/ topics pdf download/topics id $=1540000 \&$ no $=1 \&$ disp $=$ inline.

Keane, R. E., P. F. Hessburg, P. B. Landres, and F. J. Swanson. 2009. The use of historical range and variability (HRV) in landscape management. Forest Ecology and Management 258 (7):1025-1037. http://dx.doi.org/10.1016/j.foreco.2009.05.035

Keller, M., M. Palace, G. P. Asner, R. Pereira, Jr., and J. N. M. Silva. 2004. Coarse woody debris in undisturbed and logged forests in the eastern Brazilian Amazon. Global Change Biology 10(5):784-795. http://dx.doi.org/10.1111/ j.1529-8817.2003.00770.x

Kenis, M., M.-A. Auger-Rozenberg, A. Roques, L. Timms, C. Péré, M. J. W. Cock, J. Settele, S. Augustin, and C. LopezVaamonde. 2009. Ecological effects of invasive alien insects. Biological Invasions 11(1):21-45. http://dx.doi.org/10.1007/ s10530-008-9318-y

Kirby, K. R., and C. Potvin. 2007. Variation in carbon storage among trees pecies: implications for the management of a small-scale carbon sink project. Forest Ecology and Management 246(2):208-221. http://dx.doi.org/10.1016/j. foreco.2007.03.072

Kissinger, G., M. Herold, and V. De Sy. 2012. Drivers of deforestation and forest degradation: a synthesis report for REDD+ policymakers. Lexeme Consulting, Vancouver, Canada. [online] URL: https://www.gov.uk/government/ uploads/system/uploads/attachment data/file/65505/6316-driversdeforestation-report.pdf. 
Klein, A.-M., B. E. Vaissiere, J. H. Cane, I. Steffan-Dewenter, S. A. Cunningham, C. Kremen, and T. Tscharntke. 2007. Importance of pollinators in changing landscapes for world crops. Proceedings of the Royal Society B 27(1608)4:303-313. http://dx.doi.org/10.1098/rspb.2006.3721

Kleine, M., G. Shaharuddin, and P. Kant. 2009. Case studies on measuring and assessing forest degradation: addressing forest degradation in the context of joint forest management in Udaipur, India. Forest Resources Assessment Working Paper 157. Food and Agriculture Organization, Rome, Italy. [online] URL: http://www.fao.org/docrep/012/k7176e/k7176e00. pdf.

Klimes, P., C. Idigel, M. Rimandai, T. M. Fayle, M. Janda, G. D. Weiblen, and V. Novotny. 2012. Why are there more arboreal ant species in primary than in secondary tropical forests? Journal of Animal Ecology 81(5):1103-1112. http:// dx.doi.org/10.1111/j.1365-2656.2012.02002.x

Kometter, R. F., M. Martinez, A. G. Blundell, R. E. Gullison, M. K. Steininger, and R. E. Rice. 2004. Impacts of unsustainable mahogany logging in Bolivia and Peru. Ecology and Society 9(1): 12. [online] URL: http://www. ecologyandsociety.org/vol9/iss1/art12.

Lal, R., 1992. Tropical agricultural hydrology and sustainability of agricultural systems: the West Bank project (1978-1988): a ten year watershed management project in southwestern Nigeria. International Institute of Tropical Agriculture Report. Ohio State University, Columbus, Ohio, USA.

Lamb, D. 1998. Large-scale ecological restoration of degraded tropical forest lands: the potential role of timber plantations. Restoration Ecology 6(3):217-279. http://dx.doi.org/10.1046/ j.1526-100X.1998.00632.X

Lamb, D., P. D. Erskine, and J. A. Parrotta. 2005. Restoration of degraded tropical forest landscapes. Science 310:1628-1632. http://dx.doi.org/10.1126/science.1111773

Lambin, E. F. 1999. Monitoring forest degradation in tropical regions by remote sensing: some methodological issues. Global Ecology and Biogeography 8(3-4):191-198. http://dx. doi.org/10.1046/j.1365-2699.1999.00123.x

Landres, P. B., J. Verner, and J. W. Thomas. 1988. Ecological uses of vertebrate indicator species: a critique. Conservation Biology 2(4):316-328. http://dx.doi.org/10.1111/j.1523-1739.1988. $\underline{\mathrm{tb} 00195 . \mathrm{x}}$

Laurance, W. F., J. L. C. Camargo, R. C. C. Luizão, S. G. Laurance, S. L. Pimm, E. M. Bruna, P. C. Stouffer, G. B. Williamson, J. Benítez-Malvido, H. L. Vasconcelos, K. S. Van Houtan, C. E. Zartman, S. A. Boyle, R. K. Didham, A. Andrade, and T. E. Lovejoy. 2011. The fate of Amazonian forest fragments: a 32-year investigation. Biological
Conservation 114(1):56-67. http://dx.doi.org/10.1016/j. biocon.2010.09.021

Laurance, W. F., P. Delamônica, S. G. Laurance, H. L. Vasconcelos, and T. E. Lovejoy. 2000. Rainforest fragmentation kills big trees. Nature 404(6780):836. http://dx. doi.org/10.1038/35009032

Lawton, J. H., D. E. Bignell, B. Bolton, G. F. Bloemers, P. Eggleton, P. M. Hammond, M. Hodda, R. D. Holt, T. B. Larsen, N. A. Mawdsley, N. E. Stork, D. S. Srivastava, and A. D. Watt. 1998. Biodiversity inventories, indicator taxa and effects of habitat modification in tropical forest. Nature 391 (6662):72-76. http://dx.doi.org/10.1038/34166

Le Maître, D. C., B. W. van Wilgen, C. M. Gelderblom, C. Bailey, R. A. Chapman, and J. A. Nel. 2002. Invasive alien trees and water resources in South Africa: case studies of the costs and benefits of management. Forest Ecology and Management 160(1-3):143-159. http://dx.doi.org/10.1016/ $\underline{\mathrm{S} 0378-1127(01) 00474-1}$

Letouzey, R. 1985. Notice de la carte phytogéographique du Cameroun au 1:500,000. Institut de la Carte Internationale de la Végétation, Toulouse, France.

Lewandowski, A. S., R. F. Noss, and D. R. Parsons. 2010. The effectiveness of surrogate taxa for the representation of biodiversity. Conservation Biology 24(5):1367-1377. http:// dx.doi.org/10.1111/j.1523-1739.2010.01513.x

Lewis, O. T. 2009. Biodiversity change and ecosystem function in tropical forests. Basic and Applied Ecology 10 (2):97-102. http://dx.doi.org/10.1016/j.baae.2008.08.010

Lewis, S. L., G. Lopez-Gonzalez, B. Sonké, K. Affum-Baffoe, T. R. Baker, L. O. Ojo, O. L. Phillips, J. M. Reitsma, L. White, J. A. Comiskey, M.-N. Djuikouo K, C. E. N. Ewango, T. R. Feldpausch, A. C. Hamilton, M. Gloor, T. Hart, A. Hladik, J. Lloyd, J. C. Lovett, J.-R. Makana, Y. Malhi, F. M. Mbago, H. J. Ndangalasi, J. Peacock, K. S.-H. Peh, D. Sheil, T. Sunderland, M. D. Swaine, J. Taplin, D. Taylor, S. C. Thomas, R. Votere, and H. Wöll. 2009. Increasing carbon storage in intact African tropical forests. Nature 457:1003-1006. http:// dx.doi.org/10.1038/nature07771

Liao, C., Y. Luo, C. Fang, and B. Li. 2010. Ecosystem carbon stock influenced by plantation practice: implications for planting forests as a measure of climate change mitigation. Plos One 5(5): e10867. http://dx.doi.org/10.1371/journal. pone.0010867

Liebhold, A. M., W. L. MacDonald, D. Bergdahl, and V. C. Mastro. 1995. Invasion by exotic forest pests: a threat to forest ecosystems. Forest Science 41(30):a0001-z0001.

Lindenmayer, D. B., R. B. Cunningham, C. F. Donnelly, and R. Lesslie. 2002. On the use of landscape surrogates as ecological indicators in fragmented forests. Forest Ecology 
and Management 159(3):203-216. http://dx.doi.org/10.1016/ $\underline{\mathrm{S} 0378-1127(01) 00433-9}$

Linder, P., and L. Östlund. 1992. Changes in the boreal forests of Sweden 1870-1991. Svensk Botanisk Tidskrift 86:199-215.

Locatelli, B., and R. Vignola. 2009. Managing watershed services of tropical forests and plantations: Can meta-analyses help? Forest Ecology and Management 258(9):1864-1870. http://dx.doi.org/10.1016/j.foreco.2009.01.015

Lu, D., G. Li , G. S. Valladares, and M. Batistella. 2004. Mapping soil erosion risk in Rondônia, Brazilian Amazonia: using RUSLE, remote sensing and GIS. Land Degradation and Development 15(5):499-512. http://dx.doi.org/10.1002/ $\underline{\operatorname{ldr} .634}$

Lucier, A., M. Ayers, D. Karnosky, and I. Thompson. 2009. Forest responses and vulnerabilities to recent climate change. Pages 29-52 in R. Seppälä, A. Buck, and P. Katila, editors. Adaptation of forests and people to climate change: a global assessment report. IUFRO World Series Volume 22. International Union of Forest Research Organizations, Helsinki, Finland. [online] URL: http://www.iufro.org/ download/file/6990/153/Full Report pdf/.

Lugo, A. E., and F. N. Scatena. 1996. Background and catastrophic tree mortality in tropical moist, wet, and rain forests. Biotropica 28:585-599. http://dx.doi.org/10.2307/2389099

Luyssaert, S., E. D. Schulze, A. Börner, A. Knohl, D. Hessenmöller, B. E. Law, P. Ciais, and J. Grace. 2008. Oldgrowth forests as global carbon sinks. Nature 455:213-215. http://dx.doi.org/10.1038/nature07276

MacDonald, G. E. 2004. Cogongrass (Imperata cylindrica): biology, ecology, and management. Critical Reviews in Plant Sciences 23(5):367-380. http://dx.doi.org/10.1080/0735268$\underline{0490505114}$

Mack, R. N., D. Simberloff, W. M. Lonsdale, H. Evans, M. Clout, and F. A. Bazzaz. 2000. Biotic invasions: causes, epidemiology, global consequences, and control. Ecological Applications 10(3):689-710. http://dx.doi.org/10.1890/1051-0761 (2000)010[0689:BICEGC]2.0.CO;2

Manchanda, M. L., M. Kudrat, and A. K. Tiwari. 2002. Soil survey and mapping using remote sensing. Tropical Ecology 43(1):61-74.

Matricardi, E. A. T., D. L. Skole, M. A. Pedlowski, W. Chomentowski, and L. C. Fernandes. 2010. Assessment of tropical forest degradation by selective logging and fire using Landsat imagery. Remote Sensing of Environment 114 (5):1117-1129. http://dx.doi.org/10.1016/j.rse.2010.01.001

Matsushita, B., M. Xu, Y. Onda, Y. Otsuki, and M. Toyota. 2010. Detecting forest degradation in Kochi, Japan: groundbased measurements versus satellite (Terra/ASTER) remote sensing. Hydrological Processes 24(5):588-595. http://dx.doi. org/10.1002/hyp.7553

Maya, Y., B. Lacaze, M. Monteforte, and M. F. Passini. 2004. Análisis de imágenes SPOT: erosión en la región montañosa del sur de la Península de Baja California, México. Terra Latinoamericana 22(1):23-34.

McGarigal, K., S. A. Cushman, and E. Ene. 2012. FRAGSTATS v4: spatial pattern analysis program for categorical and continuous maps. Computer software program produced by the authors at the University of Massachusetts, Amherst, Massachusetts, USA. [online] URL: www.umass. edu/landeco/research/fragstats/fragstats.html.

McLaren, M. A., I. D. Thompson, and J. A. Baker. 1998. Selection of vertebrate wildlife indicators for monitoring sustainable forest management in Ontario. Forestry Chronicle 74(2):241-248.

Mery, G., P. Katila, G. Galloway, R. I. Alfaro, M. Kanninen, M. Lobovikov, and J. Varjo, editors. 2010. Forests and society: responding to global drivers of change. IUFRO World Series Volume 25. International Union of Forest Research Organizations, Vienna, Austria. [online] URL: http://www. iufro.org/science/special/wfse/forests-society-global-drivers/.

Mikuinski, G., and P. Angelstam. 1997. European woodpeckers and anthropogenic habitat change: a review. Vogelwelt-Berlin 118:277-283.

Montréal Process. 2009. Criteria and indicators for the conservation and sustainable management of temperate and boreal forests. Third edition. Montréal Process, Montreal, Canada. [online] URL: http://www.montrealprocess.org/ documents/publications/techreports/2009p 2.pdf.

Morgan, R. P. C. 2005. Soil erosion and conservation. Third edition. Blackwell, Malden, Massachusetts, USA.

Murdiyarso, D., M. Skutsch, M. Guariguata, M. Kanninen, C. Luttrell, P. Verweij, and O. Stella. 2008. Measuring and monitoring forest degradation for REDD: implications of country circumstances. CIFOR Infobriefs 16. Center for International Forest Research, Bogor, Indonesia. [online] URL: http://www.cifor.org/online-library/browse/view-publication/ publication/2596.html.

Nasi, R., and P. G. H. Frost. 2009. Sustainable forest management in the tropics: Is everything in order but the patient still dying? Ecology and Society 14(2): 40. [online] URL: www.ecologyandsociety.org/vol14/iss2/art40.

Neary, D. G., G. G. Ice, and C. R. Jackson. 2009. Linkages between forest soils and water quality and quantity. Forest Ecology and Management 258(10):2269-2281. http://dx.doi. org/10.1016/j.foreco.2009.05.027 
Nepstad, D. C., A. Verssimo, A. Alencar, C. Nobre, E. Lima, P. Lefebvre, P. Schlesinger, C. Potter, P. Moutinho, E. Mendoza, M. Cochrane, and V. Brooks. 1999. Large-scale impoverishment of Amazonian forests by logging and fire. Nature 398:505-508. http://dx.doi.org/10.1038/19066

Niemi, G. J., J. M. Hanowski, A. R. Lima, T. Nicholls, and N. Weiland. 1997. A critical analysis on the use of indicator species in management. Journal of Wildlife Management 61:1240-1252. http://dx.doi.org/10.2307/3802123

Norris, K. 2012. Biodiversity in the context of ecosystem services: the applied need for systems approaches. Philosophical Transactions of the Royal Society B 367 (1586):191-199. http://dx.doi.org/10.1098/rstb.2011.0176

Noss, R. F. 1999. Assessing and monitoring forest biodiversity: a suggested framework and indicators. Forest Ecology and Management 115(2-3):135-146. http://dx.doi. org/10.1016/S0378-1127(98)00394-6

Numata, I., M. A. Cochrane, C. M. Souza, Jr., and M. H. Sales. 2011. Carbon emissions from deforestation and forest fragmentation in the Brazilian Amazon. Environmental Research Letters 6(4): 044003. http://dx.doi.org/10.1088/17$\underline{48-9326 / 6 / 4 / 044003}$

Olander, L. P., H. K. Gibbs, M. Steininger, J. J. Swenson, and B. C. Murray. 2008. Reference scenarios for deforestation and forest degradation in support of REDD: a review of data and methods. Environmental Research Letters 3(2): 025011. [online] URL: http://iopscience.iop.org/1748-9326/3/2/025011/ pdf/1748-9326_3_2 025011.pdf. http://dx.doi. org/10.1088/1748-9326/3/2/025011

Oldroyd, B. P. and S. Wongsiri. 2006. Asian honey bees: biology, conservation, and human interactions. Harvard University Press, Cambridge, Massachusetts, USA.

Oliver, I., and A. J. Beattie. 1996. Designing a cost-effective invertebrate survey: a test of methods for rapid assessment of biodiversity. Ecological Applications 6(2):594-607. http://dx. doi.org/10.2307/2269394

Pan, Y., R. A. Birdsey, J. Fang, R. Houghton, P. E. Kauppi, W. A. Kurz, O. L. Phillips, A. Shvidenko, S. L. Lewis, J. G. Canadell, P. Ciais, R. B. Jackson, S. W. Pacala, A. D. McGuire, S. Piao, A. Rautiainen, S. Sitch, and D. Hayes. 2011. A large and persistent carbon sink in the world's forests. Science 333:988-993. http://dx.doi.org/10.1126/science.1201609

Pardini, R., A. de Arruda Bueno, T. A. Gardner, P. I. Prado, and J. P. Metzger. 2010. Beyond the fragmentation threshold hypothesis: regime shifts in biodiversity across fragmented landscapes. PLoS One 5(10): e13666. http://dx.doi. org/10.1371/journal.pone.0013666

Parry, M. L., O. F. Canziani, J. P. Palutikof, P. J. van der Linden, and C. E. Hanson, editors. 2007. Contribution of
Working Group II to the fourth assessment report of the Intergovernmental Panel on Climate Change. Cambridge University Press, Cambridge, UK. [online] URL: http://www. ipcc.ch/publications_and_data/ar4/wg2/en/contents.html.

Pejchar, L., and H. A. Mooney. 2009. Invasive species, ecosystem services and human well-being. Trends in Ecology and Evolution 24(9):497-504. http://dx.doi.org/10.1016/j. tree.2009.03.016

Peña-Claros, M., Z. Villegas, R. Guzman, and L. Poorter. 2007. Amazonia revealed: a perspective from the Amazon. Frontiers in Ecology and the Environment 5(5):237.

Peres, C. A., C. Baider, P. A. Zuidema, L. H. O. Wadt, K. A. Kainer, D. A. P. Gomes-Silva, R. P. Salomão, L. L. Simões, E. R. N. Franciosi, F. C. Valverde, R. Gribel, G. H. Shepard, Jr., M. Kanashiro, P. Coventry, D. W. Yu, A. R. Watkinson, and R. P. Freckleton. 2003a. Demographic threats to the sustainability of Brazil nut exploitation. Science 302:2112-2114. http://dx.doi.org/10.1126/science.1091698

Peres, C. A., J. Barlow, and T. Haugaasen. 2003b. Vertebrate responses to surface wildfires in a central Amazonian forest. Oryx 37(1):97-109. http://dx.doi.org/10.1017/S0030605303000188

Phat, N. K., W. Knorr, and S. Kim. 2004. Appropriate measures for conservation of terrestrial carbon stocksanalysis of trends of forest management in Southeast Asia. Forest Ecology and Management 191(1-3):283-299. http://dx. doi.org/10.1016/j.foreco.2003.12.019

Phillips, O. L., Y. Malhi, N. Higuchi, W. F. Laurance, P. V. Núñez, R. M. Vásquez, S. G. Laurance, L. V. Ferreira, M. Stern, S. Brown, and J. Grace. 1998. Changes in the carbon balance of tropical forests: evidence from long-term plots. Science 282:439-442. http://dx.doi.org/10.1126/science.282.5388.439

Pimentel, D., R. Zuniga, and D. Morrison. 2005. Update on the environmental and economic costs associated with alieninvasive species in the United States. Ecological Economics 52(3):273-288. http://dx.doi.org/10.1016/j.ecolecon.2004.10.002

Pontius, J., M. Martin, L. Plourde, and R. Hallett. 2008. Ash decline assessment in emerald ash borer-infested regions: a test of tree-level, hyperspectral technologies. Remote Sensing of Environment 112(5):2665-2676. http://dx.doi.org/10.1016/ j.rse.2007.12.011

Potvin, C., L. Mancilla, N. Buchmann, J. Monteza, T. Moore, M. Murphy, Y. Oelmann, M. Scherer-Lorenzen, B. L. Turner, W. Wilcke, F. Zeugin, and S. Wolf 2011. An ecosystem approach to biodiversity effects: carbon pools in a tropical tree plantation. Forest Ecology and Management 261 (10):1614-1624. http://dx.doi.org/10.1016/j.foreco.2010.11.015

Powers, M., R. Kolka, B. Palik, R. McDonald, and M. Jurgensen. 2011. Long-term management impacts on carbon storage in Lake States forests. Forest Ecology and 
Management 262(3):424-431. http://dx.doi.org/10.1016/j. foreco.2011.04.008

Prasannakumar, V., H. Vijith, N. Geetha, and R. Shiny. 2011. Regional scale erosion assessment of a sub-tropical highland segment in the Western Ghats of Kerala, South India. Water Resources Management 25(14):3715-3727. http://dx.doi. org/10.1007/s11269-011-9878-y

PROFOR (Program on Forests). 2010. Poverty-forests linkages toolkit. World Bank, Washington, D.C., USA. [online] URL: www.profor.info/profor/node/103.

Putz, F. E., P. A. Zuidema, M. A. Pinard, R. G. A. Boot, J. A. Sayer, D. Sheil, P. Sist, Elias, and J. K. Vanclay. 2007. Improved tropical forest management for carbon retention. Plos Biology 6(7): e166. http://dx.doi.org/10.1371/journal. pbio.0060166

Putz, F. E., P. A. Zuidema, T. Synnott, M. Peña-Claros, M. A. Pinard, D. Sheil, J. K. Vanclay, P. Sist, S. Gourlet-Fleury, B. Griscom, J. Palmer, and R. Zagt. 2012. Sustaining conservation values in selectively logged tropical forests: the attained and the attainable. Conservation Letters 5 (4):296-303. http://dx.doi.org/10.1111/j.1755-263X.2012.00242. $\underline{\mathrm{X}}$

Razafindrabe, B. H. N., B. He, S. Inoue, T. Ezaki, and R. Shaw. 2010. The role of forest stand density in controlling soil erosion: implications to sediment-related disasters in Japan. Environmental Monitoring and Assessment 160(1-4):337-354. http://dx.doi.org/10.1007/s10661-008-0699-2

Redford, K. H. 1992. The empty forest. BioScience 42 (6):412-422. http://dx.doi.org/10.2307/1311860

Repetto, R. 1990. Deforestation in the tropics. Scientific American 262(4):36-42. http://dx.doi.org/10.1038/ scientificamerican0490-36

Richardson, D. M. 1998. Forestry trees as invasive aliens. Conservation Biology 12(1):18-26. http://dx.doi.org/10.1111/ j.1523-1739.1998.96392.x

Ricketts T. H., G. C. Daily, P. R. Ehrlich, and C. D. Michener. 2004. Economic value of tropical forest to coffee production. Proceedings of the National Academy of Sciences 101 (34):12579-12582. http://dx.doi.org/10.1073/pnas.0405147101

Ritz, K., H. I. J. Black, C. D. Campbell, J. A. Harris, and C. Wood. 2009. Selecting biological indicators for monitoring soils: a framework for balancing scientific and technical opinion to assist policy development. Ecological Indicators 9 (6):1212-1221. http://dx.doi.org/10.1016/j.ecolind.2009.02.009

Rolstad, J., I. Gjerde, V. S. Gundersen, and M. Saetersdal. 2002. Use of indicator species to assess forest continuity: a critique. Conservation Biology 16(1):253-257. http://dx.doi. org/10.1046/j.1523-1739.2002.00552.x
Russell, A. E., J. W. Raich, R. Bedoya Arrieta, O. ValardeBarrantes, and E. González. 2010. Impacts of individual tree species on carbon dynamics in a moist tropical forest environment. Ecological Applications 20(4):1087-1100. http://dx.doi.org/10.1890/09-0635.1

Ryan, C. M., T. Hill, E. Woollen, C. Ghee, E. Mitchard, G. Cassells, J. Grace, I. H. Woodhouse, and M. Williams. 2012. Quantifying small-scale deforestation and forest degradation in African woodlands using radar imagery. Global Change Biology 18(1):243-257. http://dx.doi.org/10.1111/ j.1365-2486.2011.02551.x

Saatchi, S. S., N. L. Harris, S. Brown, M. Lefsky, E. T. A. Mitchard, W. Salas, B. R. Zutta, W. Buermann, S. L. Lewis, S. Hagen, S. Petrova, L. White, M. Silman, and A. Morel. 2011. Benchmark map of forest carbon stocks in tropical regions across three continents. Proceedings of the National Academy of Sciences 108(24):9899-9904. http://dx.doi. org/10.1073/pnas.1019576108

Salick, J., A. Mejia, and T. Anderson. 1995. Non-timber forest products integrated with natural forest management, Rio San Juan, Nicaragua. Ecological Applications 5(4):878-895. http://dx.doi.org/10.2307/2269339

Samejima, H., M. Marzuki, T. Nagamitsu, and T. Nakashizuka. 2004. The effects of human disturbance on a stingless bee community in a tropical rainforest. Biological Conservation 120(4):577-587. http://dx.doi.org/10.1016/j. biocon.2004.03.030

Sánchez-Azofeifa, G. A., R. C. Harriss, and D. L. Skole. 2001. Deforestation in Costa Rica: a quantitative analysis using remote sensing imagery. Biotropica 33(3):378-384. http://dx. doi.org/10.1646/0006-3606(2001)033[0378:DICRAQ]2.0.CO;2

Santos, B. A., C. A. Peres, M. A. Oliveira, A. Grillo, C. P. Alves-Costa, and M. Tabarelli. 2008. Drastic erosion in functional attributes of tree assemblages in Atlantic forest fragments of northeastern Brazil. Biological Conservation 141 (1):249-260. http://dx.doi.org/10.1016/j.biocon.2007.09.018

Sasaki, N., and F. E. Putz. 2009. Critical need for new definitions of "forest" and "forest degradation" in global climate change agreements. Conservation Letters 2 (5):226-232. http://dx.doi.org/10.1111/j.1755-263X.2009.00067. $\underline{\mathrm{X}}$

Saura, S., and P. Carballal. 2004. Discrimination of native and exotic forest patterns through shape irregularity indices: an analysis in the landscapes of Galicia, Spain. Landscape Ecology 19(6):647-662. http://dx.doi.org/10.1023/B: LAND.0000042905.97437.78

Schmidt-Vogt, D. 1998. Defining degradation: the impacts of swidden on forests in northern Thailand. Mountain Research and Development 18:135-149. http://dx.doi.org/10.2307/3673969 
Schulze, M., J. Grogan, C. Uhl, M. Lentini, and E. Vidal. 2008. Evaluating ipê (Tabebuia, Bignoniaceae) logging in Amazonia: sustainable management or catalyst for forest degradation? Biological Conservation 141(8):2071-2085. http://dx.doi.org/10.1016/j.biocon.2008.06.003

Secretariat of the Convention on Biological Diversity. 2002. Review of the status and trends of, and major threats to, the forest biological diversity. CBD Technical Series 7. Secretariat of the Convention on Biological Diversity, Montreal, Canada. [online] URL: http://www.cbd.int/doc/publications/cbdts-07.pdf.

Seeley, T. D., and R. A. Morse. 1976. The nest of the honey bee (Apis mellifera L.). Insect Sociaux 23(4):495-512. http:// dx.doi.org/10.1007/BF02223477

Seidl, R., W. Rammer, D. Jäger, W. S. Currie, and M. J. Lexer. 2007. Assessing trade-offs between carbon sequestration and timber production within a framework of multi-purpose forestry in Austria. Forest Ecology and Management 248 (1-2):64-79. http://dx.doi.org/10.1016/j.foreco.2007.02.035

Shackleton, S., P. Shanley, and O. Ndoye. 2007. Invisible but viable: recognising local markets in non-timber forest products. International Forestry Review 9(3):697-712. http:// dx.doi.org/10.1505/ifor.9.3.697

Shanley, P., and L. Luz. 2003. The impacts of forest degradation on medicinal plant use and implications for health care in eastern Amazonia. BioScience 53(6):573-584. http:// dx.doi.org/10.1641/0006-3568(2003)053[0573:TIOFDO]2.0. $\underline{\mathrm{CO} ; 2}$

Sharma, C. M., N.. P. Baduni, S. Gairola, S. K. Ghildiyal, and S. Suyal. 2010. Tree diversity and carbon stocks of some major forest types of Garhwal Himalaya, India. Forest Ecology and Management 260(12):2170-2179. http://dx.doi.org/10.1016/ j.foreco.2010.09.014

Sheil, D., R. Nasi, and B. Johnson. 2004. Ecological criteria and indicators for tropical forest landscapes: challenges in the search for progress. Ecology and Society 9(1): 7. [online] URL: http://www.ecologyandsociety.org/vol9/iss1/art7.

Shlisky, A., A. Alencar, M. Manta, and L. M. Curran. 2009. Overview: global fire regime conditions, threats, and opportunities for fire management in the tropics. Pages 65-84 in M. A. Cochrane, editor. Tropical fire ecology: climate change, land use, and ecosystem dynamics. Springer, Berlin, Germany, and Praxis, Chichester, UK. http://dx.doi. org/10.1007/978-3-540-77381-8 3

Siegert, F., G. Ruecker, A. Hinrichs, and A. A. Hoffmann. 2001. Increased damage from fires in logged forests during droughts caused by El Niño. Nature 414:437-440. http://dx. doi.org/10.1038/35106547
Sierra, R. 2001. The role of domestic timber markets in tropical deforestation and forest degradation in Ecuador: implications for conservation planning and policy. Ecological Economics 36(2):327-340. http://dx.doi.org/10.1016/S0921-8009(00)00233-0

Simberloff, D., M. A. Relva, and M. Nuñez. 2002. Gringos en el bosque: introduced tree invasion in a native Nothofagus/ Austrocedrus forest. Biological Invasions 4(1-2):35-53. http:// dx.doi.org/10.1023/A:1020576408884

Simula, M. 2009. Towards defining forest degradation: comparative analysis of existing definitions. Forest Resources Assessment Working Paper 154. Food and Agriculture Organization, Rome, Italy. [online] URL: ftp://ftp.fao.org/ docrep/fao/012/k6217e/k6217e00.pdf.

Siry, J. P., F. W. Cubbage, and M. R. Ahmed. 2005. Sustainable forest management: global trends and opportunities. Forest Policy and Economics 7(4):551-561. http://dx.doi.org/10.1016/j.forpol.2003.09.003

Slik, J. W. F., N. Raes, S.-I. Aiba, F. Q. Brearley, C. H. Cannon, E. Meijaard, H. Nagamasu, R. Nilus, G. Paoli, A. D. Poulsen, D. Sheil, E. Suzuki, J. L. C. H. Van Valkenburg, C. O. Webb, P. Wilkie, and S. Wulffraat. 2009. Environmental correlates for tropical tree diversity and distribution patterns in Borneo. Diversity and Distributions 15(3):523-532. http://dx.doi. org/10.1111/j.1472-4642.2009.00557.x

Souza, C. M., Jr., D. A. Roberts, and M. A. Cochrane. 2005. Combining spectral and spatial information to map canopy damage from selective logging and forest fires. Remote Sensing of Environment 98(2-3):329-343. http://dx.doi. org/10.1016/j.rse.2005.07.013

Strand, H., R. Höft, J. Strittholt, L. Miles, N. Horning, E. Fosnight, and W. Turner, editors. 2007. Sourcebook on remote sensing and biodiversity indicators. CBD Technical Series 32. Secretariat of the Convention on Biological Diversity, Montreal, Canada. [online] URL: http://www.cbd.int/doc/ publications/cbd-ts-32.pdf.

Straube, D., E. A. Johnson, D. Parkinson, S. Scheu, and N. Eisenhauer. 2009. Nonlinearity of effects of invasive ecosystem engineers on abiotic soil properties and soil biota. Oikos 118(6):885-896. http://dx.doi.org/10.1111/ j.1600-0706.2009.17405.x

Strayer, D. L., V. T. Eviner, J. M. Jeschke, and M. L. Pace. 2006. Understanding the long-term effects of species invasions. Trends in Ecology and Evolution 21(11):645-651. http://dx.doi.org/10.1016/j.tree.2006.07.007

Swaine, M. D., and J. B. Hall. 1976. An application of ordination to the identification of forest types. Plant Ecology 32(2):83-86. http://dx.doi.org/10.1007/BF02111902

Swift, T. L., and S. J. Hannon. 2010. Critical thresholds associated with habitat loss: a review of the concepts, 
evidence, and applications. Biological Reviews 85(1):35-53. http://dx.doi.org/10.1111/j.1469-185X.2009.00093.X

TEEB (The Economics of Ecosystems and Biodiversity). 2010. Mainstreaming the economics of nature: a synthesis of the approach, conclusions and recommendations of TEEB. Economics of Ecosystems and Biodiversity, Geneva, Switzerland. [online] URL: http://www.teebweb.org/publications/ teeb-study-reports/synthesis/.

Terborg, J., and J. A. Estes. 2010. Trophic cascades: predators, prey and the changing dynamics of nature. Island Press, Washington, D.C., USA.

Terborgh, J., G. Nuñez-Iturri, N. C. A. Pitman, F. H. Cornejo Valverde, P. Alvarez, V. Swamy, E. G. Pringle, and C. E. T. Paine. 2008. Tree recruitment in an empty forest. Ecology 89 (6):1757-1768. http://dx.doi.org/10.1890/07-0479.1

Theron, J. M., A. Van Laar, A. Kunneke, and B. V. Bredenkamp. 2004. A preliminary assessment of utilizable biomass in invading Acacia stands on the Cape coastal plains. South African Journal of Science 100(1):123-125.

Thompson, I., B. Mackey, S. McNulty, and A. Mosseler. 2009. Forest resilience, biodiversity, and climate change: a synthesis of the biodiversity/resilience/stability relationship in forest ecosystems. CBD Technical Series 43. Secretariat of the United Nations Convention on Biological Diversity, Montreal, Canada. [online] URL: http://www.cbd.int/doc/ publications/cbd-ts-43-en.pdf.

Thompson, I. D., K. Okabe, J. M. Tylianakis, P. Kumar, E. G. Brockerhoff, N. A. Schellhorn, J. A. Parrotta, and R. Nasi. 2011. Forest biodiversity and the delivery of ecosystem goods and services: translating science into policy. BioScience 61 (12):972-981. http://dx.doi.org/10.1525/bio.2011.61.12.7

Thornes, J. B. 1990. Vegetation and erosion: processes and environments. Wiley, Chichester, UK.

Thornton, D. H., L. C. Branch, and M. E. Sunquist. 2011. The relative influence of habitat loss and fragmentation: Do tropical mammals meet the temperate paradigm? Ecological Applications 21(6):2324-2333. http://dx.doi.org/10.1890/10-2124.1

Tsai, F., E.-K. Lin, and K. Yoshino. 2007. Spectrally segmented principal component analysis of hyperspectral imagery for mapping invasive plant species. International Journal of Remote Sensing 28(5):1023-1039. http://dx.doi. org/10.1080/01431160600887706

Uhl, C., and R. Buschbacher. 1985. A disturbing synergism between cattle ranch burning practices and selective tree harvesting in the eastern Amazon. Biotropica 17:265-268. http://dx.doi.org/10.2307/2388588

Uhl, C., and J. B. Kauffman. 1990. Deforestation, fire susceptibility, and potential tree responses to fire in the eastern Amazon. Ecology 71(2):437-449. http://dx.doi.org/10.2307/1940299
UNFCCC (United Nations Framework Convention on Climate Change). 2010. Report of the Conference of the Parties on its fifteenth session, held in Copenhagen from 7 to 19 December 2009. FCCC/CP/2009/11. United Nations Framework Convention on Climate Change, Copenhagen, Denmark. [online] URL: http://unfccc.int/documentation/ documents/advanced_search/items/6911.php?priref=600005734.

van der Werf, G. R., D. C. Morton, R. S. DeFries, J. G. J. Olivier, P. S. Kasibhatla, R. B. Jackson, G. J. Collatz, and J. T. Randerson. 2009. $\mathrm{CO}_{2}$ emissions from forest loss. Nature Geoscience 2:737-738. http://dx.doi.org/10.1038/ngeo671

van Wilgen, B. W., D. M. Richardson, D. C. Le Maître, C. Marais, and C. Magadlela. 2001. The economic consequences of alien plant invasions: examples of impacts and approaches to sustainable management in South Africa. Environment, Development and Sustainability 3(2):145-168. http://dx.doi. org/10.1023/A:1011668417953

Vantomme, P. 2003. Compiling statistics on non-wood forest products as policy and decision-making tools at the national level. International Forestry Review 5(2):156-160. http://dx. doi.org/10.1505/IFOR.5.2.156.17412

Vellend, M., K. Verheyen, H. Jacquemyn, A. Kolb, H. Van Calster, G. Peterken, and M. Hermy. 2006. Extinction debt of forest plants persists for more than a century following habitat fragmentation. Ecology 87(3):542-548. http://dx.doi. org/10.1890/05-1182

Vié, J.-C., C. Hilton-Taylor, and S. N. Stuart, editors. 2009. Wildlife in a changing world: an analysis of the 2008 IUCN Red List of Threatened Species. IUCN, Gland, Switzerland.

Vienna, Liaison Unit. 2003. Improved pan-European indicators for sustainable forest management. In Fourth ministerial conference on the protection of forests in Europe. Ministerial Conference on the Protection of Forests in Europe, Vienna, Austria. [online] URL: http://timberold.unece.org/ fileadmin/DAM/publications/improved-indicators-sfm.pdf.

Vieira, S., S. Trumbore, P. B. Camargo, D. Selhorst, J. Q. Chambers, N. Higuchi, and L. A. Martinelli. 2005. Slow growth rates of Amazonian trees: consequences for carbon cycling. Proceedings of the National Academy of Sciences 102 (51):18502-18507. http://dx.doi.org/10.1073/pnas.0505966102

Walker, B. H. 1992. Biodiversity and ecological redundancy. Conservation Biology 6(1):18-23. http://dx.doi.org/10.1046/ j.1523-1739.1992.610018.X

Walker, B., C. S. Holling, S. R. Carpenter, and A. Kinzig. 2004. Resilience, adaptability and transformability in socialecological systems. Ecology and Society 9(2): 5. [online] URL: http://www.ecologyandsociety.org/vol9/iss2/art5/. 
Wright, S. J., K. E. Stoner, N. Beckman, R. T. Corlett, R. Dirzo, H. C. Muller-Landau, G. Nuñez-Iturri, C. A. Peres, and B. C. Wang. 2007. The plight of large animals in tropical forests and the consequences for plant regeneration. Biotropica 39(3):289-291. http://dx.doi.org/10.1111/ j.1744-7429.2007.00293.X

Wu, J., J. Huang, X. Han, Z. Xie, and X. Gao. 2003. ThreeGorges Dam: experiment in habitat fragmentation? Science 300:1239-1240. http://dx.doi.org/10.1126/science.1083312

Yamaura, Y., S. Ikeno, M. Sano, K. Okabe, and K. Ozaki. 2009. Bird responses to broad-leaved forest patch area in a plantation landscape across seasons. Biological Conservation 142(10):2155-2165. http://dx.doi.org/10.1016/j.biocon.2009.04.015

Zhao B. G., K. Futai, J. R. Sutherland, and Y. Takeuchi, editors. 2008. Pine wilt disease. Springer, Tokyo, Japan.

Ziegler, A. D., T. W. Giambelluca, D. Plondke, S. Leisz, L. T. Tran, J. Fox, M. A. Nullet, J. B. Vogler, D. M. Troung, and T. D. Vien. 2007. Hydrological consequences of landscape fragmentation in mountainous northern Vietnam: buffering of Hortonian overland flow. Journal of Hydrology 337 (1-2):52-67. http://dx.doi.org/10.1016/j.jhydrol.2007.01.031 